\title{
Modelling forage yield and water productivity of continuous crop sequences in the Argentinian Pampas
}

Article in European Journal of Agronomy · October 2017

DOI: 10.1016/j.eja.2017.10.004

CITATION

1

6 authors, including:

\section{Jonathan Ojeda}

Tasmanian Institute of Agriculture

14 PUBLICATIONS 6 CITATIONS

SEE PROFILE

Md. Rafiqul Islam

University of Sydney

51 PUBLICATIONS 196 CITATIONS

SEE PROFILE
READS

85

\section{Keith G. Pembleton}

University of Southern Queensland

33 PUBLICATIONS 153 CITATIONS

SEE PROFILE

Sergio Carlos Garcia

University of Sydney

132 PUBLICATIONS 986 CITATIONS

SEE PROFILE

Some of the authors of this publication are also working on these related projects:

Project
State of knowledge and research priorities for lucerne crops (Medicago sativa) in Argentina View project

bomrang: Australian Government Bureau of Meteorology Data From R View project 


\section{Title}

2 Modelling forage yield and water productivity of continuous crop sequences in the

3 Argentinian Pampas

4

\section{Author Names and Affiliations}

6 J.J. Ojeda ${ }^{a, b,}{ }^{,}$, K.G. Pembleton ${ }^{c}$, O.P. Caviglia ${ }^{a, b, d}$, M.R. Islam ${ }^{e}$, M.G. Agnusdei ${ }^{f}$, S.C.

7 Garcia $^{\mathrm{e}}$

$8 \quad{ }^{a}$ National Research Council (CONICET), Argentina.

9 b Facultad de Ciencias Agropecuarias, Universidad Nacional de Entre Ríos, Ruta 11,

10 Km. 10.5 (3101), Oro Verde, Entre Ríos, Argentina.

11 jonathanjesusojeda@gmail.com

$12{ }^{c}$ University of Southern Queensland, School of Agriculture, Computational and

13 Environmental Sciences and Institute for Agriculture and the Environment,

14 Toowoomba, 4350, Queensland, Australia.

15 Keith.Pembleton@usq.edu.au

16 d Instituto Nacional de Tecnología Agropecuaria (INTA), Estación Experimental

17 Agropecuaria Paraná, Ruta 11, Km. 12.5 (3101), Oro Verde, Entre Ríos, Argentina.

18 ocaviglia2002@gmail.com

19 e Dairy Science Group, Faculty of Veterinary Science, The University of Sydney,

20 Camden, 2570, New South Wales, Australia.

21 md.islam@sydney.edu.au

sergio.garcia@sydney.edu.au

$23{ }^{f}$ Instituto Nacional de Tecnología Agropecuaria (INTA), Estación Experimental

24 Agropecuaria Balcarce, CC 276 (7620), Balcarce, Buenos Aires, Argentina.

25 agnusdei.monica@inta.gob.ar

27 * Corresponding author: Jonathan Jesus Ojeda. Instituto Nacional de Tecnología 28 Agropecuaria (INTA), Estación Experimental Agropecuaria Paraná, Ruta 11, Km 12.5 
29 (3101), Oro Verde, Entre Ríos, Argentina. Phone number: (+54) 93434158 978. E-

30 mail: jonathanjesusojeda@gmail.com

31 


\section{Abstract}

In recent years, the use of forage crop sequences (FCS) has been increased as a main component into the animal rations of the Argentinian pasture-based livestock systems. However, it is unclear how year-by-year rainfall variability and interactions with soil properties affect FCS dry matter (DM) yield in these environments. Biophysical crop models, such as Agricultural Production Systems Simulator (APSIM), are tools that enable the evaluation of crop yield variability across a wide of environments. The objective of this study was to evaluate the APSIM ability to predict forage DM yield and water productivity (WP) of multiple continuous FCS. Thirteen continuous FCS, including winter and summer crops, were simulated by APSIM during two/three growing seasons in five locations across the Argentinian Pampas. Our modelling approach was based on the simulation of multiple continuous FCS, in which crop DM yields depend on the performance of the previous crop in the same sequence and the final soil variables of the previous crop are the initial conditions for the next crop. Overall, APSIM was able to accurately simulate FCS DM yield (0.93 and $3.2 \mathrm{Mg} \mathrm{ha}^{-1}$ for concordance correlation coefficient [CCC] and root mean square error [RMSE] respectively). On the other hand, the model predictions were better for annual $\left(\mathrm{CCC}=0.94 ; \mathrm{RMSE}=0.4 \mathrm{~g} \mathrm{~m}^{-2} \mathrm{~mm}^{-1}\right)$ than for seasonal WP $\left(\mathrm{CCC}=0.71 ; \mathrm{RMSE}=1.9 \mathrm{~g} \mathrm{~m}^{-}\right.$

$50{ }^{2} \mathrm{~mm}^{-1}$ ), i.e. at the crop level. The model performance to predict WP was associated with better estimations of the soil water dynamics over the long-term, i.e. at the FCS level, rather than the short-term, i.e. at the crop level. The ability of APSIM to predict WP decreased as seasonal WP values increased, i.e. for low water inputs. For seasonal water inputs, $<200 \mathrm{~mm}$, the model tended to under-predict WP, which was directly associated with crop DM yield under-predictions for frequently harvested crops.

56 Even though APSIM showed some weaknesses in predicting seasonal DM yield and WP, i.e. at the crop level, it appears as a potential tool for further research on complementary forage crops based on multiple continuous FCS in the Argentinian livestock systems. 


\section{Keywords}

61 APSIM, forages, livestock systems, model validation, maize.

62

63 Abbreviations

64 APSIM, Agricultural Production Systems Simulator; AR-M, annual ryegrass-maize; B$65 \mathrm{M}$, barley-maize; B-M, barley-maize; B-S, barley-soybean; CCC, concordance 66 correlation coefficient; DM, dry matter; FCS, forage crop sequences; M-M, maize67 maize; O-M, oats-maize; O-S, oats-soybean; RMSE, root mean square error; W-M, 68 wheat-maize; WP, water productivity; W-S-M, wheat-soybean-maize. 69 


\section{Introduction}

Worldwide food demand is expected to increase by $60-100 \%$ by 2050 (Tilman et al., 2011; Valin et al., 2014), which include the growing demand for meat and milk (Bouwman et al., 2005; Zhang et al., 2017). This will drive an increase in forage production to supply animal feed. This increase could be achieved, at least in part, through forage crop intensification, i.e. the production of more fodder crop per unit of cultivated land (Mueller et al., 2012; Teixeira et al., 2014). Likewise, to optimize the increasingly limited land use and to avoid adverse environmental impacts, future yield increases should focus on increasing the environmental resources use efficiency, in particular water (Caviglia et al., 2004).

The Argentinian Pampas is an important livestock production region (Solbrig and Viglizzo, 1999), in which animal feed is predominantly based on forage crops sequences (FCS, i.e. sequences based on annual forage crops for silage, hay or grazing) and perennial pastures (Ojeda et al., 2016). In recent years, the sowing area of forage crops (annual and perennial) has decreased significantly in the face of the advance of grain and oilseed cropping (annual crops like soybean, wheat, barley, and sunflower) in this region. However, the decreasing area of perennial pastures has been off-set by a doubling of the area sown to annual forage crops in the last 24 years (200000 v. 100000 ha year-1 $^{-1}$, respectively) (INDEC, 1988; FAOSTAT, 2013). Likewise, the sowing area of annual silage crops has increased $300 \%$ from 2006 to 2014, with maize (Zea mays L.) accounting for $67 \%$ of this increase (Opacak, F., personal communication, CACF).

Annual forage crops are fed during periods of low growth rates of perennial pastures has been widely used to improve and stabilize the balance between supply and forage demand (Rawnsley, 2007; 2013), productivity per unit area (Garcia et al., 2008) and, water and nitrogen (N) use efficiency (Garcia et al., 2008; Neal et al., 2011). Likewise,

96 there is an increasing interest to integrate perennial pastures with FCS in order to 97 improve livestock systems productivity and stability under predicted scenarios of 
climate variability (Chapman et al., 2008a; 2011). Although the FCS are important forage resources, it is unclear how year-by-year rainfall variability and the interaction with soil type affect dry matter (DM) yield in these environments. This information is required to guide the adoption of management practices oriented to increase the livestock systems stability facing up the increasing frequency of extreme climatic events (Pembleton et al., 2016).

104 To study the spatio-temporal variability of FCS DM yield, long-term field experiments are needed which require considerable time and funding resources. An alternative is to use biophysical crop models to evaluate the FCS DM yield variability across a wide of environments to identify the most successful systems prior to field evaluation. Several simulation models have been used to predict crop growth for the evaluation of pasturebased livestock systems (Chapman et al., 2008a; 2008b; Cullen et al., 2009; Rawnsley

110 et al., 2009). The Agricultural Production Systems Simulator (APSIM) is a crop

111 simulation model that integrates through sub-modules, agronomic management with

112 climatic data in a mechanistic way to simulate growth and development of crops, as

113 well as the dynamics of soil water and N (Keating et al., 2003; Holzworth et al., 2014).

114 Although APSIM was initially created to predict crop grain yield in Australia, in the past 115 years it has appeared to be promissory to simulate forage crop DM yield across several 116 environments (e.g. Canterbury plains, New Zealand [Teixeira et al., 2010; 2015], south117 eastern Australia [Pembleton et al., 2013; 2016; Islam et al., 2015] and the Argentinian 118 Pampas [Ojeda et al., 2016]).

119 Crop modelling studies in the Argentinian Pampas also have been mainly focused on 120 grain production using Decision Support System for Agrotechnology Transfer (DSSAT) 121 (Monzon et al., 2007; Mercau et al., 2007; Caviglia et al., 2013). However, recent 122 advances have been reported simulating perennial pastures in the last years. For 123 example, Berger et al. (2014) examined DairyMod's ability to predict tall fescue 124 (Festuca arundinacea Schreb.) DM yield under contrasting seasons, N fertilizations 125 and soil water availability at Balcarce, Argentina. Also, a recent study reported by 
126 Laulhe (2015) demonstrated the DSSAT capacity to simulate the fescue DM yield in

127 two locations in the south-eastern of Buenos Aires. However, there are no reported

128 modelling studies using annual forage crop sequences for this region.

129 A useful approach to study the impact of the interaction between climate variability and

130 soil type on FCS DM yield is the water productivity (WP), estimated as the ratio

131 between DM yield and rainfall (or rainfall plus irrigation water, where relevant). This

132 metric has been widely used in natural grasslands (Noy-Meir, 1973; Le Houerou, 1984;

133 Sala et al., 1988; Lauenroth and Sala, 1992; Paruelo et al., 1999; Huxman et al., 2004;

134 Verón et al., 2005), agricultural cropping systems (Pereira et al., 2002; Sadras, 2002;

135 Molden et al., 2003; Caviglia et al., 2004; Passioura et al., 2006; Van Opstal et al., 136 2011) and could be also used in forage systems (Zhang et al., 2017).

137 Before APSIM could be used as a possible predictor of DM yield in multiple continuous

138 FCS in different Argentinian Pampas environments, an exhaustive validation process is

139 required. Particularly, the evaluation of the model ability to accurately simulate possible

140 effects of previous crops and initial soil conditions on the following crops into the

141 sequence. Likewise, an analysis of the WP year-by-year variability would allow the 142 analysis of DM yield variation due to water inputs, i.e. rainfall and irrigation. The 143 objective of this study was to evaluate the APSIM ability to predict forage DM yield and 144 water productivity (WP) of multiple continuous FCS in five locations across the 145 Argentinian Pampas under a range of inputs and crop management system. 


\section{Materials and Methods}

148 The model validation was carried-out following the subsequent steps: (i) climate data

149 and practices management were provided to APSIM, (ii) soil parametrization was

150 generated for each experiment (Table 1), (iii) graphical comparison and statistical

151 analyses of observed and modelled crop and FCS DM yields and WP. A complete

152 description of data used for APSIM validation is provided in the Table 2.

\section{2.1. Experimental locations and forage growth}

154 The FCS DM yields were collected in five locations across Argentinian Pampas: 155 Rafaela $\left(31^{\circ} 11^{\prime} \mathrm{S}, 61^{\circ} 30^{\prime} \mathrm{O}\right)$, Pergamino (335'ㅇ $\left.60^{\circ} 33^{\prime} \mathrm{O}\right)$, General Villegas $\left(35^{\circ} 01^{\prime} \mathrm{S}\right.$

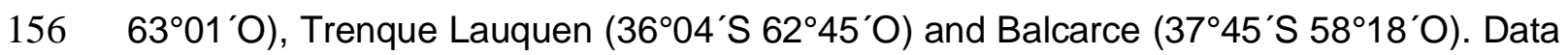
157 for APSIM validation were collected from experimental stations of the Argentinian 158 National Institute of Agriculture (INTA), except at Trenque Lauquen where were 159 collected from experiments located at the farm level. The dataset included thirteen FCS 160 DM yields of annual crops (annual ryegrass [Lolium multiflorum Lam.], oats [Avena 161 sativa L.], wheat [Triticum aestivum L.], barley [Hordeum vulgare L.], soybean [Glycine 162 max L.] and maize) from 2009 to 2015 (Fig. 1; Table 2). Each sequence was comprised 163 of two crops per year except for the wheat-soybean-maize sequence at Rafaela where 164 it included three crops per year (Fig. 1). All field experiments were carried-out under 165 dryland conditions, except at Pergamino where some sequences were irrigated (Table 166 2).

\section{2.2. Climate data}

168 The climate characteristics of each location are provided in Figure 2. Daily 169 meteorological data (daily minimum and maximum air temperature [at $1.5 \mathrm{~m}$ height], 170 solar radiation and rainfall) for each location were obtained from a meteorological 171 station, except at Trenque Lauquen where they were provided by the Climate and 172 Water Institute of INTA (CIRN) and by local researchers. Any missing daily solar 173 radiation, minimum and maximum temperature data were obtained from the NASA 174 Prediction of Worldwide Energy Resource (POWER) - Climatology Resource for 
Agroclimatology (NASA, 2013). This database provides information on historical

176 climatic series of interest locations based on geographical coordinates (latitude and

177 longitude). Recent assessments of NASA-POWER's predictive capacity showed good

178 predictions of maximum and minimum air temperature in different US (White et al.,

179 2008; Ojeda et al., 2017) and Argentinian environments (Aramburu Merlos et al.,

180 2015).

181 The maximum mean air temperature range was from 4.0 to $46.3{ }^{\circ} \mathrm{C}$ and the minimum

182 mean air temperature from -11.1 to $28.2^{\circ} \mathrm{C}$ (Fig. 2). Average cumulative annual rainfall

183 ranged from 793 to $1002 \mathrm{~mm}$ for Trenque Lauquen and Pergamino, respectively (Fig.

184 2). Similarly, the maximum soil water storage capacity between locations ranged from

$185113 \mathrm{~mm}$ at Trenque Lauquen (from 0 to $1.3 \mathrm{~m}$ soil depth) to more than the double at

186 Rafaela (264 mm, from 0 to $1.6 \mathrm{~m}$ soil depth) (Table 1 ).

$187 \quad$ 2.3. Soil data

188 The configuration of soil $\mathrm{N}$ and $\mathrm{C}$ modules (SoilM) and water balance (SoilWat) were 189 carried-out following the next steps. Soil water parameters required to the model such 190 as drained lower limit (LL), drained upper limit (DUL), bulk density (BD) and organic 191 carbon were provided by the Soils Institute of INTA (CIRN) (Table 1). Also, for each 192 soil, air dry (AD), saturated volumetric water (SAT), total porosity (PO), drainage

193 coefficient (SWCON) and soil pH were estimated according to the reported by Ojeda et 194 al. (2017) for US environments. In addition, the water extraction coefficient (KL) was 195 set at $0.08 \mathrm{~mm} \mathrm{~d}^{-1}$ (Robertson et al., 1993a, 1993b; Dardanelli et al., 1997, 2004) for 196 each soil layer. The root exploration factor (XF) was set as 1 for up to $1 \mathrm{~m}$ depth and 197 then decreased exponentially to 0.6 at the maximum soil depth (Monti and Zatta, 198 2009). To initialize the soil nitrogen pool, a 10-year simulation of previous management 199 at the experimental locations (oats-maize sequence), the location-specific climate, and 200 soil data were used (Ojeda et al., 2017). 
201 Initial simulations shown that was required the inclusion of soil water from water table

202 at Rafaela. This additional water was included into the model following Ojeda et al. 203 (2016).

\section{2.4. APSIM configuration}

205 All simulations were performed using APSIM (version 7.5) (Keating et al., 2003;

206 Holzworth et al., 2014). Oats, wheat, barley, soybean and maize were simulated with

207 the respective plant modules (APSIM-Oats, -Wheat, -Barley, Soybean and -Maize, 208 respectively; Carberry et al., 1989; Keating et al., 2003; Wang et al., 2003; Peake et al., 209 2008). Annual ryegrass was simulated with the APSIM-Weed module (Deen et al., 210 2003; Pembleton et al., 2013) re-parameterized by Ojeda et al. (2016) using the late 211 flowering genotype. Simulations were performed at the crop sequence level, i.e. the 212 initial soil condition for a specific crop was the final soil condition of the previous crop.

213 The sequences are shown in Figure 2. Since genotypes used in the field experiments

214 were not available into APSIM, we used the genotypes that best reflected the maturity 215 type/crop development among the available genotypes in the model. The actual crop 216 management such as sowing date, plant density, row spacing, nitrogen fertilization and 217 irrigation were set in the model to mimic the practices applied in the field (Table 2). The 218 harvest rule was set to remove the aerial biomass at a height of $0.03 \mathrm{~m}$ (Ojeda et al., 219 2016). Seasonal WP was calculated as the ratio between the DM yield in each crop 220 harvest and seasonal rainfall in the same period. Likewise, the annual WP was 221 calculated as the ratio between the annual DM yield for each FCS and the annual 222 rainfall.

\subsection{Evaluation of APSIM performance}

224 First, the model performance was assessed to predict crop and FCS DM yield. After 225 that, APSIM's ability to sense spatio-temporal variability in the FCS DM yield and WP 226 was evaluated. The assessment was based on the comparison between observed and 227 modelled values by scatter plots (Piñeiro et al., 2008) for crops and FCS DM yield in all 228 locations. 
229 The evaluation of model performance described in Tedeschi (2006) was used to 230 statistically evaluate APSIM to predict crop and FCS DM yields. The statistical 231 parameters used were: observed and modelled mean and standard deviation, 232 coefficient of determination $\left(\mathrm{R}^{2}\right)$, root mean square error (RMSE) and the concordance 233 correlation coefficient (CCC). The CCC integrates precision through Pearson's 234 correlation coefficient, which represents the proportion of the total variance in the 235 observed data that can be explained by APSIM, and accuracy by bias which indicates 236 how far the regression line deviates from the line $(1: 1)$.

237 The crop model performance was categorically judged based on the values of CCC as 238 proposed by Stöckle et al. (1998). Upper and lower statistical limits were set as: "very 239 good" when CCC $>0.90$, "satisfactory" when $0.80<C C C<0.90$, "acceptable" when $240 \quad 0.70<\mathrm{CCC}<0.80$ and "poor" with other values. 


\section{Results}

\section{3.1. Dry matter yield}

244 The observed crop DM yield ranged from 1.4 $\mathrm{Mg} \mathrm{ha}^{-1}$ (annual ryegrass) to $14.9 \mathrm{Mg} \mathrm{ha}^{-1}$ 245 (maize). The difference between observed and modelled crop mean DM yield was 0.2 $246 \mathrm{Mg} \mathrm{ha}^{-1}$, being higher in crops with lowest number of observations (wheat and barley,

247 Table 3). A better model accuracy to predict DM yield was found when maize DM 248 yields from 2010/11 were deleted. In this year, the maximum temperatures during 249 summer were extreme $\left(>40^{\circ} \mathrm{C}\right.$; Fig. 2) and the extractable soil water was close to $\mathrm{LL}$ 250 (Fig. 4). After removing these data, the CCC increased from 0.80 to 0.86 and the 251 RMSE decreased from 4.1 to $3.4 \mathrm{Mg} \mathrm{ha}^{-1}$. Likewise, better model predictions were obtained by simulating crops for silage, i.e. only one harvest for wheat, soybean and maize, than when crops were harvested successively (annual ryegrass, oats and 254 barley) (Fig. 3; Table 3).

255 The crop DM yield at Pergamino dryland and irrigated, Rafaela and Balcarce was 256 simulated more accurately compared to the crop DM yield modelled at General Villegas 257 and Trenque Lauquen (Table 3; Fig. 3). Likewise, the model accuracy in simulating DM 258 yield under irrigated conditions at Pergamino was slightly lower compared to dryland conditions. However, the observations at Pergamino irrigated $(n=26)$ were less than

260 half that the observations at Pergamino dryland $(n=60)$.

261 Overall, the model had a very good ability to simulate DM yields of FCS. The 262 performance of the model in predicting FCS DM yield is highlighted in Figures 5 and 6 and confirmed by the summary statistics in Table 4 (CCC $=0.83-0.95, \mathrm{RMSE}=2.3-5.0$

$264 \mathrm{Mg} \mathrm{ha}^{-1}$ ). The observed FCS DM yield ranged from 4.3 $\mathrm{Mg} \mathrm{ha}^{-1}$ (Trenque Lauquen) to 28.7 $\mathrm{Mg} \mathrm{ha}^{-1}$ (Rafaela) among locations (Table 4) and from $16.2 \mathrm{Mg} \mathrm{ha}^{-1}$ (third year of the sequence) to $19.1 \mathrm{Mg} \mathrm{ha}^{-1}$ (first year of the sequence) among years (Table 4). The

267 difference between observed and modelled mean FCS DM yield was less than $0.2 \mathrm{Mg}$ $268 \mathrm{ha}^{-1}$, being the lowest under irrigation at Pergamino (0.7 $\mathrm{Mg} \mathrm{ha}^{-1}$; Table 4) and the 269 highest at Rafaela (3.7 $\mathrm{Mg} \mathrm{ha}^{-1}$; Table 4). The sequences annual ryegrass-maize (AR- 
$270 \mathrm{M}$ ) and barley-soybean (B-S) at General Villegas and the sequences oats-soybean (O-

271 S) and barley-maize (B-M) at Trenque Lauquen had the lowest observed and modelled 272 FCS DM yield (Fig. 5a) while the highest DM yields were found for maize-maize (M-M) 273 and wheat-soybean-maize (W-S-M) at Rafaela and oats-maize (O-M) at Balcarce (Fig.

$2745 a)$. Due to the small number of observations that were available for Trenque Lauquen

275 and Balcarce, no statistical analyses of DM yield at the level of FCS were performed

276 (Table 4). The FCS DM yield under irrigation at Pergamino was simulated more 277 accurately than in the same site without irrigation, Rafaela and General Villegas (Table 278 4; Fig. 3). The model over-predicted the FCS DM yield at Rafaela, mainly due to the 279 over-prediction of maize DM yield (Fig. 5b; Fig. 6a). There were no discernible 280 groupings based on years in the data points for all sequences. For all FCS, DM yield was better simulated as the crops progressed in their development (Fig. 6), except in some specific cases. For example, maize into the sequence wheat-maize (W-M) at

283 Rafaela during 2011 (Fig. 6a) and barley into the sequence barley-maize (B-M) at 284 Trenque Lauquen during 2010 (Fig. 6d).

\subsection{Water productivity}

Very good agreement between observed and modelled seasonal WP was found at Balcarce $\left(\mathrm{CCC}=0.90, \mathrm{RMSE}=0.7 \mathrm{~g} \mathrm{~m}^{-2} \mathrm{~mm}^{-1}\right.$; Table 5). However, the model's ability to predict seasonal WP was acceptable at Pergamino under both dryland and irrigated conditions $\left(\mathrm{CCC}=0.73-0.74, \mathrm{RMSE}=2.0-2.5 \mathrm{~g} \mathrm{~m}^{-2} \mathrm{~mm}^{-1}\right.$; Table 5) and poor at Rafaela $\left(\mathrm{CCC}=0.55, \mathrm{RMSE}=1.3 \mathrm{~g} \mathrm{~m}^{-2} \mathrm{~mm}^{-1}\right)$, Trenque Lauquen $\left(\mathrm{CCC}=0.51, \mathrm{RMSE}=1.0 \mathrm{~g} \mathrm{~m}^{-2}\right.$ $\mathrm{mm}^{-1}$ ) and General Villegas (CCC $=0.42$, RMSE $=1.4 \mathrm{~g} \mathrm{~m}^{-2} \mathrm{~mm}^{-1}$ ) (Table 5). At Pergamino, dryland and irrigated, the observed seasonal WP shown extreme values because seasonal rainfall between oats and annual ryegrass harvests was scarce $(<20$ mm, Fig. 8a). For seasonal water inputs (i.e. rainfall + irrigation) less than $200 \mathrm{~mm}$, the model under-predicted WP values more than over-predicted (Fig. 7a). However, the model predictions on an annual basis were very good (Fig. 7b). 
297 The model predicted annual WP with very good accuracy, as demonstrated by $298 \mathrm{CCC}=0.91-0.96$ and $\mathrm{RMSE}=0.2-0.5 \mathrm{~g} \mathrm{~m}^{-2} \mathrm{~mm}^{-1}$ for the total observations (Table 5), 299 except for Rafaela where the model under-predicted $\left(0.5 \mathrm{~g} \mathrm{~m}^{-2} \mathrm{~mm}^{-1} ; 12 \%\right)$ the annual 300 WP $\left(\mathrm{CCC}=0.62, \mathrm{RMSE}=0.7 \mathrm{~g} \mathrm{~m}^{-2} \mathrm{~mm}^{-1}\right)$. Likewise, the observed and modelled 301 seasonal WP were on average 95 and $21 \%$ superior at Rafaela, Pergamino under

302 both dryland and irrigated conditions and Balcarce than at General Villegas and

303 Trenque Lauquen, except for the modelled WP at Pergamino (Table 5). However, the 304 observed and modelled annual WP at Rafaela was higher than Pergamino and, in turn 305 higher at Pergamino than at General Villegas and Trenque Lauquen (Table 5).

306 There was a better fit for the observed than for the modelled WP data (Fig. 8a; Table 6) 307 in the regression of the WP as a function of seasonal water inputs (cumulative rainfall + 308 irrigation) $(\mathrm{P}<0.001$; Table 6). Likewise, a better fit was found for winter crops (oats, 309 annual ryegrass, barley and wheat) and soybean than for maize (Fig. 8a; Table 6).

310 Similarly, there was a curvilinear relationship between annual WP and water inputs ( $p$ $311<0.001)$ for both observed and modelled data (Fig. 8b; Table 6). At low annual water 312 inputs (<800 mm), in General Villegas and Trenque Lauquen the WP, on average, was 313 only a third than in other locations (Fig. 8b). 


\section{Discussion}

316 In this study, 13 FCS including winter (oats, annual ryegrass, barley and wheat) and

317 summer crops (soybean and maize), were simulated by APSIM across five Argentinian

318 locations. Our objective was to evaluate the APSIM ability to predict DM yield and

319 water productivity (WP) of multiple continuous FCS. Overall, the results showed that

320 APSIM was able to simulate better DM yield and WP on an annual basis, i.e. at the

321 FCS level, than at a seasonal basis, i.e. at the crop level.

322 The ability of APSIM to predict crops DM yield in the Argentinian Pampas was similar

323 to annual forage crop modelling efforts reported in south-eastern Australia (Pembleton

324 et al., 2013; 2016; Islam et al., 2015) and New Zealand (Teixeira et al., 2010; 2015).

325 The model accuracy was higher when predicting soybean and maize DM yield than the

326 other crops. The APSIM-Oats module had an acceptable performance since it is has

327 received scarce development efforts compared to the other modules used in this study

328 (Peake et al., 2008; Pembleton et al., 2013). The very good and satisfactory model

329 accuracy when predicting soybean and maize DM yields, respectively, was not

330 surprising, since both modules (APSIM-Soybean and APSIM-Maize) have been widely

331 evaluated across diverse environments for their ability to predict grain and DM yield

332 (Robertson and Carberry, 1998; Denner et al., 1998; Shamudzarira and Robertson,

333 2002; Lyon et al., 2003; Teixeira et al., 2010; Mohanty et al., 2012; Liu et al., 2013;

334 Pembleton et al., 2013; Archontoulis et al., 2014a, 2014b). However, the model under-

335 predicted maize DM yields at Rafaela mainly during the first year of simulation (Fig. 3a

336 and Fig. 6). Surprisingly, the $\mathrm{N}$ fertilization rate to this crop at Rafaela was relatively low

337 (0.075 $\left.\mathrm{Mg} \mathrm{N} \mathrm{ha}^{-1}\right)$ for the high recorded mean DM yield (17.5 $\left.\mathrm{Mg} \mathrm{ha}^{-1}\right)$. Although

338 previous studies have reported that APSIM-Sugarcane module was scarcely sensitive

339 to variations in the initial soil $N$ at US environments (Ojeda et al., 2017), our study

340 demonstrated a high model response for maize in this location of the Argentinian

341 Pampas (Fig. A.1). The mentioned under-predictions of maize DM yield at Rafaela

342 could be attributed to the under-estimation of initial soil $\mathrm{N}$ at this location because of 
343 the soil initialization method used in this study based on a 10-year sequence simulation

344 of oats-maize as previous crops. In fact, Teixeira et al. (2015) reported the importance

345 to choose representative initialization values for soil water and $\mathrm{N}$ in studies that often 346 consider several soil types. On the other hand, Ojeda et al. (2017) found that APSIM

347 predictions of Miscanthus DM yield were more sensitive to changes in the initial organic

348 carbon on a sandy soil than in a silty soil at US. Collectively, this reinforces the

349 importance of the initial soil conditions on the accuracy of DM yield and WP simulations

350 of different FCS under several input intensities. Therefore, further research should be

351 addressed to clarify the extent of under or over-estimation of initial soil parameters on

352 the predictions of continuous FCS DM yield and WP using APSIM.

353 Although APSIM had a very good accuracy when predicting barley DM yield

$354(\mathrm{CCC}=0.90 ;$ Table 3$)$, the model over-predicted the barley DM yield (5 out of 5

355 observations) as was demonstrated by the difference between observed and modelled

356 mean DM yield (1.7 Mg ha-1; Table 3). Previous studies in southern Queensland,

357 Australia, found that the APSIM-Barley module was able to explain 91 and $82 \%$ of the

358 variation observed in total biomass at maturity and grain yield, respectively (Manschadi

359 et al., 2006). However, their study was based on the calibration of only one Australian

360 barley genotype (Grimmet). Probably, the low fit between observed and modelled

361 mean DM yield at General Villegas and Trenque Lauquen (Fig. 3d and Fig. 3e) would

362 be due to genotypic differences between the currently available genotypes into the

363 model and those used in the field experiments as well as the method of soil

364 initialization as mentioned above.

365 The model accuracy to predict silage DM yield of individual crops (barley, wheat, 366 soybean and maize), i.e. a single harvest by season, was better than to predict DM

367 yield of frequently harvested crops (annual ryegrass, oats and barley), i.e. several

368 harvest by season (Fig. 3). This model response was not surprising as APSIM was

369 initially developed to simulate grain crops managed with only one final harvest at 370 maturity. The main reason for this model's inability would be related to the absence of 
371 APSIM calibrations using forage crop phenology data and with the model settings

372 related to the biomass remaining after each harvest which is directly involved in the

373 following forage regrowth (Ojeda et al., 2016).

374 The predictions of FCS DM yield across the Argentinian Pampas were very good (Fig.

375 5; Table 4), which were similar to the APSIM simulations reported by Teixeira et al.

376 (2010) in New Zealand using double crops (wheat and triticale [X. triticosecale,

377 Wittmack] as winter crops and maize and kale [Brassica oleracea L.] as summer

378 crops). In the same way, our results were comparable with modelling efforts reported

379 by Islam et al. (2015) for FCS DM yield in dairy systems in south-eastern Australia.

380 Similarly, these authors found high DM yield achieved from maize-based FCS

381 compared with FCS based on other summer crops (soybean and forage sorghum

382 [Sorghum bicolor (L.) Moench]) due to the high yield potential of maize.

383 Soil variables required as model inputs to initialization of the simulation (e.g. water, C

384 and N) are habitually re-initialized (i.e. are set in each simulation using constant values

385 based on regional knowledge) (Teixeira et al., 2015). Despite the soil variables were

386 set only once previous to the first crop sowing into the FCS the first year of the

387 simulation, APSIM demonstrated high robustness to simulate DM yield of several FCS

388 (Fig. 5) in wide edaphoclimatic and temporal conditions in the Argentinian Pampas.

389 This modelling approach considers that the crop DM yields in the FCS depend on the

390 previous crop in the same sequence, carrying the final soil variables of the previous

391 year as the initial ones for the next year. White et al. (2011) reported that from 166

392 modelling papers that considered adaptation strategies (i.e. sowing date, fertilization

393 rate, irrigation, cultivars and crop rotations), only 11 papers compared crop rotations. In

394 fact, most crop modelling assessments consider simulations of the same crop over

395 consecutive years (White et al., 2011). However, there are only a few studies that used

396 the FCS approach, i.e. simulating crop rotations. For example, Teixeira et al. (2015)

397 evaluated the effects to use different APSIM simulation (at the individual crop and

398 sequence level) on DM yield, soil water and $\mathrm{N}$ in the Canterbury plains of New 
Zealand. These authors reported greater model sensitivity to the simulation when the

400 crops grown under restrictive soil water and $\mathrm{N}$ levels. Therefore, they proposed that a

401 more detailed representation of the simulations at the sequences level would be key to

402 accurately simulating crop growth under limited resources conditions, where the

403 sequence effect would have greater influence on the subsequent crops growth.

404 The use of complementary forage systems based on FCS as an option to maximize

405 WP was reported in south-eastern Australia under non-limiting $\mathrm{N}$ and water conditions

406 by Garcia et al. (2008) and Islam and Garcia (2012) winter crops/maize triple crops

407 (forage rape, persian clover [T. resupinatum L.], and field peas [Pisum sativum L.] as

408 winter crops). These authors reported WP values ranging $3.4-6.1 \mathrm{~g} \mathrm{~m}^{-2} \mathrm{~mm}^{-1}$ for

409 different $\mathrm{N}$ rates and sowing dates. The WP range modelled in our study $\left(1.0-4.0 \mathrm{~g} \mathrm{~m}^{-2}\right.$

$410 \mathrm{~mm}^{-1}$ ) was consistent with values reported by Caviglia et al. $(2004 ; 2013)$ for wheat-

411 soybean sequences at Balcarce (calculated using DM yield on an annual basis).

412 However, there is no study in the literature on modelling that analyze the WP variations

413 of FCS in the Argentinian Pampas, despite that WP has been widely reported for grain

414 crops sequences in this region.

415 The results showed that APSIM was able to predict with better accuracy the annual

416 (very good) than seasonal WP (acceptable) (Table 5) as was demonstrated by the

417 CCC and RMSE for the annual $\left(0.71 ; 0.4 \mathrm{~g} \mathrm{~m}^{-2} \mathrm{~mm}^{-1}\right)$ and seasonal WP $\left(0.94 ; 1.9 \mathrm{~g} \mathrm{~m}^{-}\right.$

$418{ }^{2} \mathrm{~mm}^{-1}$ ), respectively (Table 5). This model response could be due to the annual

419 estimation which considers the rainfall in a year period (from 1 July to 31 May) while

420 seasonal estimation only considers rainfall occurred in short-time periods, i.e. from

421 sowing to harvest and between two consecutive harvests (in some cases $<20 \mathrm{~d}$ ), and

422 therefore the soil water storage is not accounted. Likewise, the model's ability to predict

423 seasonal WP was not acceptable for all locations (Table 5). These results suggest that,

424 in environments such as Trenque Lauquen characterized by a low cumulative annual 425 rainfall $(793 \mathrm{~mm})$ and low maximum soil water storage capacity $(113 \mathrm{~mm})$, soil water 426 conditions carried by the model from one crop to the next, would play an important role 
427 to obtain better FCS DM yield predictions, even more under soil water stress 428 conditions.

429 The highest seasonal WP, both observed and modelled, were obtained at Rafaela 430 (Table 5), which can be attributed to the highest proportion of maize in the FCS (Fig.

431 1), which is a C4 species with a high-water use efficiency (Neal et al., 2011; Zhang et 432 al., 2017). The use of the double crop maize-maize (M-M) in this location was related 433 with the climate characteristics, where the optimal solar radiation and temperature 434 conditions allow to grow two summer crops (Monzon et al., 2014) in the same season 435 (Fig. 2).

436 The lowest observed and modelled WP values at General Villegas and Trenque 437 Lauquen (Fig. 8b) were probably associated with the reduction in DM yield of maize 438 due to the high temperatures and low rainfall during the spring-summer period (Fig. 4). 439 Therefore, the FCS DM yield was highly dependent on maize performance in these 440 locations. In fact, the WP was lower in these locations than in Rafaela or Balcarce (Fig. $4418 b$ ), which had more favourable climate conditions during spring-summer period (not 442 shown). Thus, maize DM yield seems to be critical to maximize WP in FCS.

443 The model's accuracy decreased when seasonal WP values were higher, i.e. for low 444 water inputs (Fig. 7a). For seasonal water inputs (rainfall + irrigation) less than 200 $445 \mathrm{~mm}$, the model tended to under-predict WP (Fig. 7a). This model response was directly 446 associated with crop DM yield under-predictions for crops with frequent harvests. 447 Similarly, high APSIM under-predictions were reported by Ojeda et al. (2016) for the 448 first harvest of annual ryegrass in the period during the crop establishment at 449 Pergamino and General Villegas, Argentina. This model weakness to under-predict DM 450 yield of frequently harvested crops directly affect the model performance to predict WP 451 at this environments. A deeper discussion of this model limitation is provided in Ojeda 452 et al. (2016), who mentioned the predictions of DM yield of annual ryegrass improved 453 substantially when several key model parameters (e.g. shoot_lag, shoot_rate, 454 leaf_no_at_emerg and transp_eff_c) were well calibrated. Therefore, important 
modelling efforts are still required for simulate a wide range frequently harvested crop using APSIM, since it model was originally developed for simulate crops with a single harvest by season.

458 Our results showed that APSIM predicted WP better on an annual basis (Fig. 7b) than for a seasonal basis (Fig. 7a). It is likely that the model is better at estimating soil water dynamics over the long-term rather than the short-term. Likewise, the high seasonal WP values at low water inputs (Fig. 8a) reflect more a weakness of the WP concept than of the model performance, i.e. high DM yields (observed or modelled), which are reached by using soil water storage, results in elevated WP values at low seasonal water inputs.

We also have presented evidence that when annual water inputs are high, the annual WP is low (Fig. 8b; Table 6). Likewise, a better fit was found for crops with photosynthetic metabolism C3 (wheat, annual ryegrass, oats, barley and soybean) than for C4 (maize; Fig. 8a; Table 6). This response was not surprising because WP reductions against water inputs increments has been well established in Bangladesh (Ali and Talukder, 2008) in the South-eastern Pampas (Caviglia et al., 2013), in the Loess Plateau region of China (Zhang et al., 2017) and in several environments across

472 the world (Zhang et al., 2001). Also, we found higher WP values for maize than C3 473 species for the same water input from 200 to $900 \mathrm{~mm}$ (Fig. 8a) directly linked with the 474 high photosynthetic capacity of maize to convert water into DM yield (Neal et al., 2011). 475 This highlights the importance of including maize as a part of FCS to increase the WP 476 in the Argentinian livestock systems, although the impact of their inclusion may vary 477 among locations according soil water holding capacity, rainfall and the high 478 temperature stress during summer season.

479 The APSIM model will be a useful resource for further research on complementary 480 forage crops based on multiple continuous FCS and perennial crops in the Argentinian 481 and alike livestock systems. In addition, in this work we found evidence that the maize 482 inclusion as a part of a FCS was very important to maximize DM yield and WP in some 
483 locations. However, it may increase the year-by-year variability of both DM yield and 484 WP, particularly in locations with low soil water holding capacity, high temperatures 485 stress and low rainfall during the spring-summer period, such as south-western 486 Pampas.

487 


\section{Conclusions}

489 In this paper, we evaluated the APSIM ability to predict forage DM yield and WP of 490 multiple continuous FCS. Even though APSIM showed some weaknesses to 491 reasonably predict seasonal DM yield and WP, i.e. at the crop level, it appears as a 492 potential tool for further research on complementary forage crops based on multiple 493 continuous FCS in the Argentinian livestock systems. The impact of initial soil 494 conditions on the accuracy of DM yield and WP simulations seems to be critical to 495 improve APSIM performance, especially under water-limited growth conditions.

496 The model accuracy to predict silage DM yield of individual crops (barley, wheat, 497 soybean and maize), i.e. a single harvest by season, was better than to predict DM 498 yield of frequently harvested crops (annual ryegrass, oats and barley), i.e. several 499 harvest by season. 


\section{Acknowledgments}

502 The authors thank the different contributors to the dataset which allowed model 503 validation: O.D. Bertín, J.A. Castaño, M. Maekawa, M.C. Sardiña, L.A. Romero, J. 504 Villar. The field experiments were funded by INTA (Project AEFP-262921 and PNPA505 11260714). The present work is a part of the thesis submitted by J.J. Ojeda to the

506 Postgraduate program of FCA-UNMdP. J.J. Ojeda held a postdoctoral research 507 fellowship and O.P. Caviglia is a member of CONICET, the National Research Council 508 of Argentina.

509 


\section{References}

511

512 Ali, M.H., Talukder, M.S.U., 2008. Increasing water productivity in crop production-a $513 \quad$ synthesis. Agr. Water Manage. 95, 1201-1213.

$514 \quad$ http://doi.org/10.1016/j.agwat.2008.06.008

515

516 Aramburu Merlos, F.A., Monzon, J.P., Mercau, J.L., Taboada, M., Andrade, F.H., Hall, 517 A.J., Jobbagy, E., Cassman, K.G., Grassini P., 2015. Potential for crop production 518 increase in Argentina through closure of existing yield gaps. Field Crop. Res. 184, $519 \quad 145-154$.

$520 \quad$ http://doi.org/10.1016/j.fcr.2015.10.001

521

522 Archontoulis, S.V., Miguez, F.E., Moore, K.J., 2014a. A methodology and an 523 optimization tool to calibrate phenology of short-day species included in the APSIM 524 PLANT model: Application to soybean. Environ. Modell. Softw. 62, 465-477. 525 http://doi.org/10.1016/j.envsoft.2014.04.009

526

527 Archontoulis, S.V., Miguez, F.E., Moore, K.J., 2014b. Evaluating APSIM maize, soil 528 water, soil nitrogen, manure, and soil temperature modules in the Midwestern $529 \quad$ United States. Agron. J. 106, 1025-1040.

$530 \quad$ http://doi:10.2134/agronj2013.0421

531

532 Berger, H., Machado, C.F., Agnusdei, M., Cullen, B.R., 2014. Use of a biophysical 533 simulation model (DairyMod) to represent tall fescue pasture growth in Argentina.

$534 \quad$ Grass Forage Sci. 69, 441-453.

535 http://doi.org/10.1111/gfs.12064

536 
537 Bouwman, A.F., Van Der Hoek, K.W., Eickhout, B., Soenario, I., 2005. Exploring

538 changes in world ruminant production systems. Agr. Syst. 84, 121-153.

539 http://doi.org/10.1016/j.agsy.2004.05.006

540

541 Carberry, P.S., Muchow, R.C., McCown, R.L., 1989. Testing the CERES-Maize

542 simulation model in a semi-arid tropical environment. Field Crop. Res. 20, 297-315.

$543 \quad$ https://doi.org/10.1016/0378-4290(89)90072-5

544

545 Caviglia, O.P., Sadras, V.O., Andrade, F.H., 2004. Intensification of agriculture in the 546 south-eastern Pampas: I. Capture and efficiency in the use of water and radiation in 547 double-cropped wheat-soybean. Field Crop. Res. 87, 117-129.

$548 \quad$ http://doi.org/10.1016/j.fcr.2003.10.002

550 Caviglia, O.P., Sadras, V.O., Andrade, F.H., 2013. Modelling long-term effects of 551 cropping intensification reveals increased water and radiation productivity in the South-eastern Pampas. Field Crop. Res. 149, 300-311.

554

Chapman, D.F., Kenny, S.N., Beca, D., Johnson, I.R., 2008a. Pasture and forage crop http://doi.org/10.1016/j.fcr.2013.05.003 systems for non-irrigated dairy farms in southern Australia 2. Inter-annual variation

560 Chapman, D.F., Kenny, S.N., Beca, D., Johnson, I.R., 2008b. Pasture and crop options 561 for non-irrigated dairy farms in southern Australia. 1. Physical production and 562 economic performance. Agr. Syst. 97, 108-125.

$563 \quad$ http://doi.org/10.1016/j.agsy.2008.02.001 
565 Chapman, D.F., Kenny, S.N., Lane, N., 2011. Pasture and forage crop systems for

566 non-irrigated dairy farms in southern Australia: 3. Estimated economic value of

567 additional home-grown feed. Agr. Syst. 104, 589-599.

$568 \quad$ http://doi.org/10.1016/j.agsy.2011.06.001

569

570 Cullen, B.R., Johnson, I.R., Eckard, R.J., Lodge, G.M., Walker, R.G., Rawnsley, R.P.,

571 McCaskill, M.R., 2009. Climate change effects on pasture systems in south-eastern

$572 \quad$ Australia. Crop Pasture Sci. 60, 933-942.

$573 \quad$ https://doi.org/10.1071/CP09019

574

575 Dardanelli, J.L., Bacheier, O.A., Sereno, R., Gil, R., 1997. Rooting depth and soil water

576 extraction patterns of different crops in a silty loam Haplustoll. Field Crop. Res. 54, $577 \quad 29-38$

$578 \quad$ https://doi.org/10.1016/S0378-4290(97)00017-8

579

580 Dardanelli, J.L., Ritchie, J.T., Calmon, M., Andriani, J.M., Collino, D.J., 2004. An

581 empirical model for root water uptake. Field Crop. Res. 87, 59-71.

$582 \quad$ http://doi.org/10.1016/j.fcr.2003.09.008

583

584 Deen, W., Cousens, R., Warringa, J., Bastiaans, L., Carberry, P., Rebel, K., Riha, S., 585 Murphy, C., Benjamin, L.R., Cloughley, C., Cussans, J., Forcella, F., Hunt, T., 586 Jamieson, P., Lindquist, J., Wang, E., 2003. An evaluation of four crop: weed 587 competition models using a common data set. Weed Res. 43, 116-129. http://doi.org/10.1046/j.1365-3180.2003.00323.x

590 Denner, M.T., James, A.T., Robertson, M.J., Fukai, S., 1998. Optimum soybean $591 \quad$ cultivars for possible expansion area: a modelling approach. Proceedings $10^{\text {th }}$ 592 Australian Soybean Conference, Brisbane, Australia. pp. 137-141. 
FAOSTAT, 2013. Food and agriculture data. http://www.fao.org/faostat/en/\#home/ (accessed 10.11.13).

Garcia, S.C., Fulkerson, W.J., Brookes, S.U., 2008. Dry matter production, nutritive value and efficiency of nutrient utilization of a complementary forage rotation compared to a grass pasture system. Grass Forage Sci. 63, 1-17. http://doi.org/10.1111/j.1365-2494.2008.00636.x

600

Holzworth, D., Huth, N.I., DeVoil, P.G., Zurcher, E.J., Herrmann, N.I., McLean, G., Chenu, K., van Oosterom, E., Snow, V., Murphy, C., Moore, A.D., Brown, H., Whish, J.P.M., Verrall, S., Fainges, J., Bell, L.W., Peake, A.S., Poulton, P.L., Hochman, Z., Thorburn, P.J., Gaydon, D.S., Dalgliesh, N.P., Rodriguez, D., Cox, H., Chapman, S., Doherty, A., Teixeira, E., Sharp, J., Cichota, R., Vogeler, I., Li, F.Y., Wang, E., Hammer, G.L., Robertson, M.J., Dimes, J., Whitbread, A.M., Hunt, J., van Rees, H., McClelland, T., Carberry, P.S., Hargreaves, J.N.G., MacLeod, N., McDonald, C., Harsdorf, J., Wedgwood, S., Keating, B.A., 2014. APSIM-evolution

613 Huxman, T.E., Smith, M.D., Fay, P.A., Knapp, A.K., Shaw, M.R., Loik, M.E., Smith, 614 S.D., Tissue, D.T., Zak, J.C., Weltzin, J.F., Pockman, W.T., Sala, O.E., Haddad, towards a new generation of agricultural systems simulation. Environ. Modell. Softw. 62, 327-350.

616 B.M., Harte, J., Koch, G.W., Schwinning, S., Small, E.E., Williams, D.G., Convergence across biomes to a common rain-use efficiency. Nature. 429, 651654, 2004.

618 http://doi.org/10.1038/nature02561

619 
620 INDEC, 1988. Censo Nacional Agropecuario. Instituto Nacional de Estadísticas y

621 Censos, Buenos Aires. 152 p.

622

623 Islam, M.R., Garcia, S.C., 2012. Effects of sowing date and nitrogen fertilizer on forage 624 yield, nitrogen- and water-use efficiency and nutritive value of an annual triple-crop 625 complementary forage rotation. Grass Forage Sci. 67, 96-110.

$626 \quad$ http://doi.org/10.1111/j.1365-2494.2011.00825.x

627

628 Islam, M.R., Garcia, S.C., Clark, C.E.F., Kerrisk, K.L., 2015. Modelling pasture-based 629 automatic milking system herds: grazeable forage options. Asian Austral. J. Anim. $630 \quad 28,703-715$. https://doi.org/10.5713/ajas.14.0384

632

Keating, B.A., Carberry, P.S., Hammer, G.L., Probert, M.E., Robertson, M.J., 634 Holzworth, D., Huth, N.I., Hargreaves, J.N.G., Meinke, H., Hochman, Z., McLean, G., Verburg, K., Snow, V., Dimes, J.P., Silburn, M., Wang, E., Brown, S., Bristow, K.L., Asseng, S., Chapman, S., McCown, R.L., Freebairn, D.M., Smith, C.J., 2003. An overview of APSIM, a model designed for farming systems simulation. Eur. J. Agron. 18, 267-288. http://doi.org/10.1016/S1161-0301(02)00108-9

640

641 Lauenroth, W.K., Sala, O.E., 1992. Long-term forage production of North American 642 shortgrass steppe. Ecol. Appl. 2, 397-403.

$643 \quad$ http://doi.org/10.2307/1941874

644 Laulhe, I. 2015. Modelación de la sustentabilidad productiva y económica de sistemas 645 agrícolas, mixtos y ganaderos en el sur de Buenos Aires. Tesis Magíster Scientiae 646 en Producción Animal. Facultad de Ciencias Agrarias, Universidad Nacional de $647 \quad$ Mar del Plata. Balcarce, Argentina. pp. 144. 
648 Le Houerou, H.N., 1984. Rain use efficiency: a unifying concept in arid-land ecology. J.

$649 \quad$ Arid Environ. 7, 213-247.

650

651 Liu, Z., Hubbard, K.G., Lin, X., Yang, X., 2013. Negative effects of climate warming on

652 maize yield are reversed by the changing of sowing date and cultivar selection in

$653 \quad$ Northeast China. Glob. Change Biol. 19, 3481-3492.

$654 \quad$ http://doi.org/10.1111/gcb.12324

655

656 Lyon, D.J., Hammer, G.L., Mclean, G.B., Blumenthal, J.M., 2003. Simulation 657 supplements field studies to determine no-till dryland corn population 658 recommendations for semiarid western Nebraska. Agron. J. 95, 884-891.

$659 \quad$ http://doi.org/doi:10.2134/agronj2003.8840

660

661 Manschadi, A.M., Hochman, Z., Mclean, G., DeVoil, P., Holzworth, D., Meinke, H., 662 2006. APSIM-Barley model - Adaptation of a wheat model to simulate barley 663 growth and development. $13^{\text {th }}$ Australian Agronomy Conference, Perth, Australia. 664 pp. 239-243.

665 http://www.regional.org.au/au/asa/2006/poster/technology/4609_manschadia.htm 666

667 Mercau, J.L., Dardanelli, J.L., Collino, D.J., Andriani, J.M., Irigoyen, A., Satorre, E.H., 668 2007. Predicting on-farm soybean yields in the pampas using CROPGRO-soybean. 669 Field Crop. Res. 100, 200-209.

$670 \quad$ http://doi.org/10.1016/j.fcr.2006.07.006

671 Mohanty, M., Probert, M.E., Reddy, K.S., Dalal R.C., Mishra, A.K., Subba Rao, A., 672 Singh, M., Menzies, N.W., 2012. Simulating soybean-wheat cropping system: 673 APSIM model parameterization and validation. Agr. Ecosyst. Environ. 152, 68-78.

674 http://doi.org/10.1016/j.agee.2012.02.013

675 
676 Molden, D., Murray-Rust, H., Sakthivadivel, R., Makin, I., 2003. A water-productivity 677 framework for understanding and action. Water productivity in agriculture: Limits 678 and opportunities for improvement. International Water Management Institute, 679 Colombo, Sri Lanka. 18 pp.

680 http://publications.iwmi.org/pdf/H032632.pdf

681

682 Monti, A., Zatta, A., 2009. Root distribution and soil moisture retrieval in perennial and 683 annual energy crops in Northern Italy. Agr. Ecosyst. Environ. 132, 252-259.

684 http://doi.org/10.1016/j.agee.2009.04.007

685

686 Monzon, J.P., Sadras, V.O., Abbate, P.A., Caviglia, O.P., 2007. Modelling 687 management strategies for wheat-soybean cropping systems in the Southern 688 Pampas. Field Crop. Res. 101, 44-52.

689 http://doi.org/10.1016/j.fcr.2006.09.007

690

691 Monzon, J.P., Mercau, J.L., Andrade, J.F., Caviglia, O.P., Cerrudo, A.G., Cirilo, A.G., 692 Vega, C.R.C., Andrade, F.H., Calviño, P.A., 2014. Maize-soybean intensification 693 alternatives for the Pampas. Field Crop. Res. 162, 48-59.

694 http://doi.org/10.1016/j.fcr.2014.03.012

695

696 Mueller, N.D., Gerber, J.S., Johnston, M., Ray, D.K., Ramankutty, N., Foley, J.A., 697 2012. Closing yield gaps through nutrient and water management. Nature. 490, $698 \quad 254-257$.

699 http://doi.org/10.1038/nature11420

700

NASA, 2013. Prediction of Worldwide Energy Resource. http://power.larc.nasa.gov 702 (accessed 12.5.13). 
704 Neal, J.S., Fulkerson, W.J., Hacker, R.B., 2011. Differences in water use efficiency 705 among annual forages used by the dairy industry under optimum and deficit $706 \quad$ irrigation. Agr. Water Manage. 98, 759-774.

707 http://doi.org/10.1016/j.agwat.2010.11.011

708

709

Noy-Meir, I. 1973. Desert Ecosystems: Environment and Producers. Annu. Rev. Ecol. Syst. 4, 25-51. http://doi.org/10.1146/annurev.es.04.110173.000325

712

713 Ojeda, J.J., Pembleton, K.G., Islam, M.R., Agnusdei, M.G., Garcia, S.C., 2016. Evaluation of the agricultural production systems simulator simulating Lucerne and annual ryegrass dry matter yield in the Argentine Pampas and south-eastern Australia. Agr. Syst. 143, 61-75. http://doi.org/10.1016/j.agsy.2015.12.005

Ojeda, J.J., Volenec, J.J., Brouder, S.M., Caviglia, O.P., Agnusdei, M.G., 2017. Evaluation of Agricultural Production Systems Simulator (APSIM) as yield predictor of Panicum virgatum and Miscanthus $\mathrm{x}$ giganteus in several US environments. Glob. Change Biol. Bioenergy. 9, 796-816. http://doi.org/10.1111/gcbb.12384

Paruelo, J.M., Lauenroth, W.K., Burke, I.C., Sala, O.E., 1999. Grassland precipitationuse efficiency varies across a resource gradient. Ecosystems. 2, 64-68. http://doi.org/10.1007/s100219900058

Passioura, J. 2006. Increasing crop productivity when water is scarce-from breeding to field management. Agr. Water Manage. 80, 176-196. 
732 Peake, A., Whitbread, A., Davoren, B., Braun, J., Limpus, S., 2008. The development 733 of a model in APSIM for the simulation of grazing oats and oaten hay, in: Unkovich, 734 M. (Ed.) Global issues. Paddock action. Proceedings of $14^{\text {th }}$ Agronomy Conference. $735 \quad$ Adelaide, Australia. 4 p.

736 http://www.regional.org.au/au/asa/2008/poster/farming-uncertain-

737 climate/5846_peakeas.htm

738

739 Pembleton, K.G., Rawnsley, R.P., Jacobs, J.L., Mickan, F.J., O’brien, G.N., Cullen, 740 B.R., Ramilan, T., 2013. Evaluating the accuracy of the Agricultural Production 741 Systems Simulator (APSIM) simulating growth, development, and herbage nutritive 742 characteristics of forage crops grown in the south-eastern dairy regions of Australia. Crop Pasture Sci. 64, 147-164. https://doi.org/10.1071/CP12372

Pembleton, K.G., Cullen, B.R., Rawnsley, R.P., Harrison, M.T., Ramilan, T., 2016. Modelling the resilience of forage crop production to future climate change in the dairy regions of Southeastern Australia using APSIM. J. Agr. Sci. 154, 1131-1152. https://doi.org/10.1017/S0021859615001185

Pereira, L.S., Oweis, T., Zairi, A., 2002. Irrigation management under water scarcity. Agr. Water Manage. 57, 175-206. http://doi.org/10.1016/S0378-3774(02)00075-6

754 Piñeiro, G.; Perelman, S.; Guerschman, J.P.; Paruelo, J.M. 2008. How to evaluate 755 models: observed vs. predicted or predicted vs. observed? Ecol. Model. 216, 316322. http://doi.org/10.1016/j.ecolmodel.2008.05.006 
Rawnsley, R.P. 2007. A review of fodder crops grown in Tasmania, Invited Paper, in: Grasslands Society of Southern Australia $16^{\text {th }}$ Annual Conference, Tasmanian Branch. Launceston, Australia. pp. 31-37.

762

763 Rawnsley, R.P., Cullen, B.R., Turner, L.R., Donaghy, D.J., Freeman, M., Christie, K.M., 2009. Potential of deficit irrigation to increase marginal irrigation response of perennial ryegrass (Lolium perenne L.) on Tasmanian dairy farms. Crop Pasture Sci. $60,1156-1164$. https://doi.org/10.1071/CP08446

768

Rawnsley, R.P., Chapman, D.F., Jacobs, J.L., Garcia, S.C., Callow, M.N., Edwards, G.R., Pembleton, K.P. 2013. Complementary forages-integration at a whole-farm level. Anim. Prod. Sci. 53, 976-987. https://doi.org/10.1071/AN12282

Robertson, M.J., Fukai, S., Ludlow, M.M., Hammer, G.L., 1993a. Water extraction by grain sorghum in a sub-humid environment. I. Analysis of the water extraction pattern. Field Crop. Res. 33, 81-97. https://doi.org/10.1016/0378-4290(93)90095-5

Robertson, M.J., Fukai, S., Ludlow, M.M., Hammer, G.L.,1993b. Water extraction by grain sorghum in a sub-humid environment. II. Extraction in relation to root growth. Field Crop. Res. 33, 99-112.

Robertson, M.J., Carberry, P.S., 1998. Simulating growth and development of soybean https://doi.org/10.1016/0378-4290(93)90096-6 in APSIM. In Proceedings $10^{\text {th }}$ Australian soybean conference, Brisbane, Australia. pp. 15-17. 
Sadras, V.O. 2002. Interaction between rainfall and nitrogen fertilisation of wheat in environments prone to terminal drought: economic and environmental risk analysis. Field Crop. Res. 77, 201-215.

Sala, O.E., Parton, W.J., Joyce, L.A., Lauenroth, W.K., 1988. Primary production of the central grassland region of the United States. Ecology, 69, 40-45. http://doi.org/10.2307/1943158

Shamudzarira, Z., Robertson, M.J., 2002. Simulating response of maize to nitrogen fertilizer in semi-arid Zimbabwe. Exp. Agr. 38, 79-96. https://doi.org/10.1017/S0014479702000170

799

800 Solbrig, O.T., Viglizzo, E.F., 1999. Sustainable farming in the Argentine Pampas: 801 history, society, economy and ecology. DRCLAS, Working Papers on Latin America (Paper No. 99/00-1), Harvard University, Cambridge, MA. pp. 45. http://citeseerx.ist.psu.edu/viewdoc/download?doi=10.1.1.202.7923\&rep=rep1\&typ

804 $\mathrm{e}=\mathrm{pdf}$

805

806 Stöckle, C.O., Bellocchi, G., Nelson, R., 1998. Evaluation of the weather generator 807 ClimGen for several world locations. 7th Int. Congr. for Comp. Tech. in Agric., 15$808 \quad 18$ November, Florence, Italy, 34-41.

809 Tedeschi, L.O., 2006. Assessment of the adequacy of mathematical models. Agr. Syst. $810 \quad 89,225-247$.

811 http://doi.org/10.1016/j.agsy.2005.11.004

812

813 Teixeira, E.I.; Brown, H.; Chakwizira, E.; De Ruiter, J. 2010. Predicting yield and 814 biomass nitrogen of forage crop rotations in New Zealand using the APSIM model, 

in: DOVE, H.; CULVENOR, R.A. (Eds.) Food Security from Sustainable Agriculture.

816 Proceedings of $15^{\text {th }}$ Agronomy Conference, Lincoln, New Zealand. pp. 1-4.

817 http://www.regional.org.au/au/asa/2010/pastures-forage/forage-

$818 \quad$ crops/7073_teixeiraei.htm

819

820 Teixeira, E.I., George, M., Herreman, T., Brown, H.E., Fletcher, A., Chakwizira, E., De

821 Ruiter, J., Maley, S., Noble, A., 2014. The impact of water and nitrogen limitation on

822 maize biomass and resource-use efficiencies for radiation, water and nitrogen.

$823 \quad$ Field Crop. Res. 168, 109-118.

824 http://doi.org/10.1016/j.fcr.2014.08.002

825

826 Teixeira, E.I., Brown, H.E., Sharp, J., Meenken, E.D., Ewert, F., 2015. Evaluating

827 methods to simulate crop rotations for climate impact assessments-A case study on

828 the Canterbury plains of New Zealand. Environ. Modell. Softw. 72, 304-313.

829 http://doi.org/10.1016/j.envsoft.2015.05.012

830

831 Tilman, D., Balzer, C., Hill, J., Befort, B.L., 2011. Global food demand and the

832 sustainable intensification of agriculture. P. Natl. Acad. Sci. USA. 108, 2026083320264.

834 http://doi.org/10.1073/pnas.1116437108

836 Valin, H., Sands, R.D., van der Mensbrugghe, D., Nelson, G.C., Ahammad, H., Blanc, 837 E., Bodirsky, B., Fujimori, S., Hasegawa, T., Havlik, P., Heyhoe, E., Kyle, P., 838 Mason-D'Croz, D., Paltsev, S., Rolinski, S., Tabeau, A., van Meijl, H., von Lampe, 839 M., Willenbockel, D. (2014). The future of food demand: understanding differences 840 in global economic models. Agricultural Economics, 45, 51-67.

$841 \quad$ http://doi:10.1111/agec.12089 
843 Van Opstal, N.V., Caviglia, O.P., Melchiori, R.J.M., 2011. Water and solar radiation

844 productivity of double-crops in a humid temperate area. Aust. J. Crop Sci. 5, 1760$845 \quad 1766$.

846 http://search.informit.com.au/documentSummary;dn=005430436841146;res=IELH SS

848

849 Verón, S. R., Oesterheld, M., Paruelo, J. M. (2005). Production as a function of 850 resource availability: slopes and efficiencies are different. J. Veg. Sci. 16, 351-354. http://dx.doi.org/10.1658/1100-9233(2005)016[0351:PAAFOR]2.0.CO;2

852

853 Wang, E., Van Oosterom, E.J., Meinke, H., Asseng, S., Robertson, M., Huth, N., Keating, B., Probert, M., 2003. The new APSIM-Wheat model-performance and future improvements, in: Unkovich, M., O'leary, G., (Eds.) Solutions for a better environment. Proceedings of the $11^{\text {th }}$ Australian Agronomy Conference. Geelong, Victoria. Australia.

859

860 White, J.W., Hoogenboom, G., Stackhouse, P.W., Hoell, J.M., 2008. Evaluation of $861 \quad$ NASA satellite-and assimilation model-derived long-term daily temperature data 862 over the continental US. Agr. Forest Meteorol. 148, 1574-1584.

863 http://doi.org/10.1016/j.agrformet.2008.05.017

864 White, J.W., Hoogenboom, G., Kimball, B.A., Wall, G.W., 2011. Methodologies for 865 simulating impacts of climate change on crop production. Field Crop. Res. 124, $866 \quad 357-368$.

867 http://doi.org/10.1016/j.fcr.2011.07.001 
869 Zhang, L., Dawes, W.R., Walker, G.R., 2001. Response of mean annual 870 evapotranspiration to vegetation changes at catchment scale. Water Resour. Res. $871 \quad 37,701-708$.

872 http://doi.org/10.1029/2000WR900325

873

874 Zhang, Z., Whish, J.P., Bell, L.W., Nan, Z., 2017. Forage production, quality and water875 use-efficiency of four warm-season annual crops at three sowing times in the Loess $876 \quad$ Plateau region of China. Eur. J. Agron. 84, 84-94.

877 http://doi.org/10.1016/j.eja.2016.12.008 
1 Table 1. Soil parameters used to configure Agricultural Production Systems Simulator (APSIM).

\begin{tabular}{|c|c|c|c|c|c|c|c|c|c|c|c|c|c|c|c|}
\hline \multirow{3}{*}{ Location } & \multirow{3}{*}{ Soil type ${ }^{1}$} & \multirow{3}{*}{ Soil series } & \multirow{2}{*}{ Depth } & \multicolumn{3}{|c|}{ Texture class } & \multirow{2}{*}{$\mathrm{BD}$} & \multirow{2}{*}{ Air Dry } & \multirow{2}{*}{ LL } & \multirow{2}{*}{ DUL } & \multirow{2}{*}{ SAT } & \multirow{2}{*}{$\mathrm{PO}$} & \multirow{2}{*}{ SWCON } & \multirow{2}{*}{$\mathrm{OC}$} & \multirow{2}{*}{$\mathrm{pH}$} \\
\hline & & & & sand & silt & clay & & & & & & & & & \\
\hline & & & $m$ & $\%$ & $\%$ & $\%$ & $\begin{array}{l}M g \\
m^{-3}\end{array}$ & & $-m m n$ & & & $(0-1)$ & day $^{1}$ & $\%$ & $1: 5$ \\
\hline \multirow[t]{7}{*}{ RAF } & Typic & Rafaela & $0-0.2$ & 2 & 72 & 26 & 1.26 & 0.066 & 0.132 & 0.295 & 0.328 & 0.52 & 0.34 & 1.47 & 6.2 \\
\hline & Argiudoll & & $0.2-0.35$ & 3 & 69 & 28 & 1.29 & 0.098 & 0.140 & 0.300 & 0.333 & 0.50 & 0.33 & 0.90 & 6.3 \\
\hline & & & $0.35-0.63$ & 2 & 60 & 38 & 1.37 & 0.144 & 0.180 & 0.310 & 0.342 & 0.47 & 0.32 & 0.51 & 6.5 \\
\hline & & & $0.63-0.93$ & 2 & 58 & 41 & 1.35 & 0.165 & 0.183 & 0.319 & 0.352 & 0.48 & 0.31 & 0.37 & 6.7 \\
\hline & & & $0.93-1.15$ & 2 & 65 & 33 & 1.31 & 0.167 & 0.185 & 0.305 & 0.337 & 0.50 & 0.33 & 0.24 & 7.2 \\
\hline & & & $1.15-1.4$ & 1 & 68 & 31 & 1.28 & 0.158 & 0.175 & 0.292 & 0.322 & 0.51 & 0.34 & 0.17 & 7.4 \\
\hline & & & 1.4-1.6 & 5 & 65 & 30 & 1.28 & 0.135 & 0.150 & 0.284 & 0.313 & 0.51 & 0.35 & 0.11 & 8.2 \\
\hline \multirow[t]{6}{*}{ PER } & Typic & Pergamino & $0-0.13$ & 13 & 65 & 23 & 1.27 & 0.089 & 0.178 & 0.326 & 0.362 & 0.51 & 0.31 & 1.69 & 5.9 \\
\hline & Argiudoll & & $0.13-0.25$ & 12 & 65 & 23 & 1.32 & 0.125 & 0.178 & 0.327 & 0.363 & 0.49 & 0.31 & 1.48 & 6.1 \\
\hline & & & $0.25-0.34$ & 13 & 57 & 30 & 1.33 & 0.155 & 0.193 & 0.356 & 0.393 & 0.49 & 0.28 & 0.87 & 6.2 \\
\hline & & & $0.34-0.75$ & 9 & 48 & 44 & 1.33 & 0.204 & 0.226 & 0.418 & 0.461 & 0.49 & 0.24 & 0.64 & 6.3 \\
\hline & & & $0.75-0.95$ & 13 & 56 & 30 & 1.33 & 0.174 & 0.193 & 0.355 & 0.392 & 0.49 & 0.28 & 0.35 & 6.5 \\
\hline & & & $0.95-1.6$ & 18 & 66 & 17 & 1.33 & 0.145 & 0.160 & 0.293 & 0.323 & 0.49 & 0.34 & 0.24 & 6.4 \\
\hline \multirow[t]{6}{*}{ GV } & Typic & Blaquier & $0-0.2$ & 69 & 19 & 12 & 1.26 & 0.038 & 0.075 & 0.174 & 0.193 & 0.52 & 0.57 & 1.29 & 6.3 \\
\hline & Hapludoll & & $0.2-0.28$ & 69 & 18 & 13 & 1.29 & 0.055 & 0.078 & 0.164 & 0.182 & 0.50 & 0.61 & 1.17 & 6.3 \\
\hline & & & $0.28-0.57$ & 66 & 19 & 15 & 1.37 & 0.061 & 0.076 & 0.163 & 0.180 & 0.47 & 0.61 & 0.60 & 6.0 \\
\hline & & & $0.57-0.89$ & 75 & 14 & 11 & 1.35 & 0.059 & 0.065 & 0.143 & 0.158 & 0.48 & 0.70 & 0.18 & 6.5 \\
\hline & & & $0.89-1.25$ & 77 & 14 & 10 & 1.31 & 0.056 & 0.062 & 0.125 & 0.138 & 0.50 & 0.80 & 0.07 & 6.8 \\
\hline & & & $1.25-1.6$ & 77 & 14 & 10 & 1.28 & 0.056 & 0.062 & 0.125 & 0.138 & 0.51 & 0.80 & 0.07 & 6.8 \\
\hline \multirow[t]{5}{*}{ TL } & Entic & Piedritas & $0-0.28$ & 61 & 25 & 15 & 1.37 & 0.035 & 0.070 & 0.170 & 0.189 & 0.47 & 0.59 & 1.29 & 7.1 \\
\hline & Hapludoll & & $0.28-0.47$ & 65 & 21 & 15 & 1.38 & 0.031 & 0.061 & 0.182 & 0.202 & 0.47 & 0.55 & 0.86 & 8.3 \\
\hline & & & $0.47-0.84$ & 64 & 24 & 12 & 1.22 & 0.023 & 0.045 & 0.133 & 0.147 & 0.53 & 0.75 & 0.35 & 8.3 \\
\hline & & & $0.84-1.08$ & 75 & 13 & 12 & 1.30 & 0.033 & 0.065 & 0.121 & 0.134 & 0.50 & 0.83 & 0.13 & 8.8 \\
\hline & & & $1.08-1.3$ & 70 & 21 & 9 & 1.22 & 0.049 & 0.097 & 0.209 & 0.231 & 0.53 & 0.48 & 0.09 & 9.3 \\
\hline \multirow[t]{5}{*}{ BAL } & Petrocalcic & Balcarce & $0-0.23$ & 33 & 41 & 26 & 1.15 & 0.085 & 0.169 & 0.280 & 0.393 & 0.56 & 0.36 & 3.28 & 7.0 \\
\hline & Paleoudoll & & $0.23-0.31$ & 35 & 39 & 26 & 1.15 & 0.105 & 0.150 & 0.276 & 0.387 & 0.56 & 0.36 & 2.26 & 7.4 \\
\hline & & & $0.31-0.54$ & 36 & 29 & 35 & 1.27 & 0.142 & 0.178 & 0.351 & 0.498 & 0.51 & 0.28 & 1.59 & 7.4 \\
\hline & & & $0.54-0.70$ & 45 & 31 & 24 & 1.27 & 0.194 & 0.215 & 0.427 & 0.507 & 0.51 & 0.23 & 0.82 & 7.8 \\
\hline & & & $0.70-1.2$ & 50 & 31 & 19 & 1.35 & 0.179 & 0.199 & 0.396 & 0.450 & 0.48 & 0.25 & 0.64 & 7.8 \\
\hline
\end{tabular}

point); DUL, upper drainage limit (i.e. field capacity); SAT, saturated volumetric water.

${ }^{1}$ Soil Survey Staff, 2010. 
Table 2. Summary of the agronomic management of forage crops sequences used for model validation.

\begin{tabular}{|c|c|c|c|c|c|c|c|c|c|}
\hline \multirow[b]{2}{*}{ Location } & \multirow[b]{2}{*}{ SEQ } & \multirow[b]{2}{*}{$\mathrm{D} / \mathrm{I}$} & \multirow[b]{2}{*}{ SD } & \multirow[b]{2}{*}{$H D$} & \multicolumn{4}{|c|}{ Crop management } & \multirow[b]{2}{*}{ References } \\
\hline & & & & & $\begin{array}{c}\text { Fert N } \\
\left(\mathrm{kg} \mathrm{N} \mathrm{ha}^{-1}\right)\end{array}$ & $\begin{array}{c}\text { Density } \\
\text { (plants } \mathrm{m}^{-2} \text { ) }\end{array}$ & $\begin{array}{l}\text { RS } \\
(\mathrm{m})\end{array}$ & Genotype & \\
\hline \multicolumn{10}{|c|}{ annual ryegrass } \\
\hline PER & S-AR & $\mathrm{D}$ & 1-Mar-10 & 18-May/10-Jun/8-Jul/10-Ago/13-Sep/12-Oct-10 & 250 & 300 & 0.175 & Barturbo & EEA Pergamino \\
\hline PER & $\mathrm{M}-\mathrm{AR}$ & $\mathrm{D}$ & 1-Mar-10 & 18-May/10-Jun/8-Jul/10-Ago/13-Sep-10 & 250 & 300 & 0.175 & Barturbo & Ojeda et al., 2016 \\
\hline PER & S-AR & $\mathrm{D}$ & $28-F e b-11$ & 10-May/8-Jun/21-Jul/29-Ago/6-Oct-11 & 250 & 300 & 0.175 & Caleufú PV & \\
\hline PER & $\mathrm{M}-\mathrm{AR}$ & $\mathrm{D}$ & $28-F e b-11$ & 10-May/8-Jun/21-Jul/29-Aug & 250 & 300 & 0.175 & Caleufú PV & \\
\hline PER & S-AR & $\mathrm{D}$ & $28-F e b-12$ & 30-May/10-Jul/23-Aug/21-Sep/12-Oct-12 & 250 & 300 & 0.175 & Caleufú PV & \\
\hline PER & M-AR & $\mathrm{D}$ & $28-F e b-12$ & 30-May/10-Jul/23-Aug/21-Sep-12 & 250 & 300 & 0.175 & Caleufú PV & \\
\hline GV & $A R^{1}-M$ & $\mathrm{D}$ & $8-A p r-10$ & 22-Jun/18-Aug/7-Oct-10 & 150 & 365 & 0.175 & Bill max & EEA G. Villegas \\
\hline GV & $A R^{1}-M$ & $\mathrm{D}$ & 8-Apr-10 & 19-Sep-10 & 150 & 400 & 0.175 & Bill max & Ojeda et al., 2016 \\
\hline GV & $A R^{2}-M$ & $\mathrm{D}$ & 15-Apr-11 & 2-Sep/17-Oct-11 & 150 & 448 & 0.175 & Bill max & \\
\hline GV & $\mathrm{AR}^{2}-\mathrm{M}$ & $\mathrm{D}$ & 15-Apr-11 & $28-O c t-11$ & 150 & 400 & 0.175 & Bill max & \\
\hline \multicolumn{10}{|c|}{ oats } \\
\hline PER & $\mathrm{M}-\mathrm{O}$ & $\mathrm{D} / \mathrm{I}$ & 1-Mar-10 & 27-Apr/1-Jun/6-Jul/13-Sep-10 & 250 & 252 & 0.175 & Violeta INTA & EEA Pergamino \\
\hline PER & $\mathrm{M}-\mathrm{O}$ & $\mathrm{D} / \mathrm{I}$ & 1-Mar-11 & 26-Apr/30-May/11-Jul/25-Ago-11 & 250 & 323 & 0.175 & Violeta INTA & unpublished data \\
\hline PER & $\mathrm{M}-\mathrm{O}$ & $\mathrm{D} / \mathrm{I}$ & 1-Mar-12 & 2-May/5-Jun/14-Aug/21-Sep-12 & 250 & 341 & 0.175 & Violeta INTA & \\
\hline PER & S-O & $\mathrm{D} / \mathrm{I}$ & 1-Mar-10 & 27-Apr/1-Jun/6-Jul/13-Sep/12-Oct-10 & 250 & 252 & 0.175 & Violeta INTA & \\
\hline PER & S-O & $\mathrm{D} / \mathrm{l}$ & $28-F e b-11$ & 26-Apr/30-May/11-Jul/25-Aug/3-Oct-11 & 250 & 323 & 0.175 & Violeta INTA & \\
\hline PER & S-O & $\mathrm{D} / \mathrm{I}$ & 1-Mar-12 & 2-May/5-Jun/14-Aug/21-Sep/12-Oct-12 & 250 & 341 & 0.175 & Violeta INTA & \\
\hline BAL & $\mathrm{M}-\mathrm{O}$ & $\mathrm{D}$ & 7-Mar-13 & 16-May/29-Aug-13 & 150 & 300 & 0.200 & Bonaerense INTA & Ojeda J.J. \\
\hline BAL & $\mathrm{M}-\mathrm{O}$ & $\mathrm{D}$ & 16-Apr-14 & 11-Jul/20-Aug/8-Oct-14 & 150 & 300 & 0.200 & Bonaerense INTA & unpublished data \\
\hline $\mathrm{TL}$ & O-S & $\mathrm{D}$ & 19-Apr-10 & $8-O c t-10$ & 0 & 125 & 0.175 & Victoria & AER T. Lauquen \\
\hline $\mathrm{TL}$ & O-S & $\mathrm{D}$ & 8-Jul-11 & $20-$ Oct- 11 & 0 & 125 & 0.175 & Cristal & unpublished data \\
\hline \multicolumn{10}{|c|}{ wheat } \\
\hline RAF & W-M & $\mathrm{D}$ & $21-A p r-10$ & $25-O c t-10$ & 75 & 200 & 0.175 & - & EEA Rafaela INTA \\
\hline RAF & W-S-M & $\mathrm{D}$ & 1-Jul-10 & $16-$ Nov-10 & 75 & 200 & 0.175 & - & unpublished data \\
\hline RAF & W-M & $\mathrm{D}$ & 19-May-11 & 14-Sep-11 & 75 & 200 & 0.175 & - & \\
\hline RAF & W-S-M & $\mathrm{D}$ & 2-Jul-11 & $27-O c t-11$ & 75 & 200 & 0.175 & - & \\
\hline \multicolumn{10}{|c|}{ barley } \\
\hline GV & B-S & $\mathrm{D}$ & 8-Apr-10 & 22-Jun/19-Oct-10 & 150 & 350 & 0.175 & Scarlet & EEA G. Villegas \\
\hline GV & B-S & $\mathrm{D}$ & 15-Apr-11 & 10-Aug/4-Nov-11 & 150 & 350 & 0.175 & Scarlet & unpublished data \\
\hline $\mathrm{TL}$ & B-M & $\mathrm{D}$ & 11-Jun-10 & $15-$ Nov-10 & 0 & 120 & 0.175 & Scarlett & AER T. Lauquen \\
\hline $\mathrm{TL}$ & B-M & $\mathrm{D}$ & 8-Jul-11 & 20-Oct-11 & 0 & 120 & 0.175 & Scarlett & unpublished data \\
\hline \multicolumn{10}{|c|}{ soybean } \\
\hline RAF & W-S-M & $\mathrm{D}$ & $20-$ Nov-10 & 1-Mar-11 & 0 & 30 & 0.52 & - & EEA Rafaela INTA \\
\hline RAF & W-S-M & $\mathrm{D}$ & $15-\mathrm{Nov}-11$ & 7-Feb-12 & 0 & 30 & 0.52 & - & unpublished data \\
\hline PER & S-O & $\mathrm{D} / \mathrm{I}$ & 10-Nov-09 & $25-F e b-10$ & 13 & 42 & 0.70 & ADM $50048(5)^{3}$ & EEA Pergamino \\
\hline PER & S-AR & $\mathrm{D}$ & 10-Nov-09 & $25-F e b-10$ & 13 & 42 & 0.70 & ADM $50048(5)^{3}$ & unpublished data \\
\hline PER & $\mathrm{S}-\mathrm{O}$ & $\mathrm{D} / \mathrm{I}$ & 4-Nov-10 & $25-F e b-11$ & - & 45 & 0.52 & GAPP $890(8)^{3}$ & \\
\hline
\end{tabular}




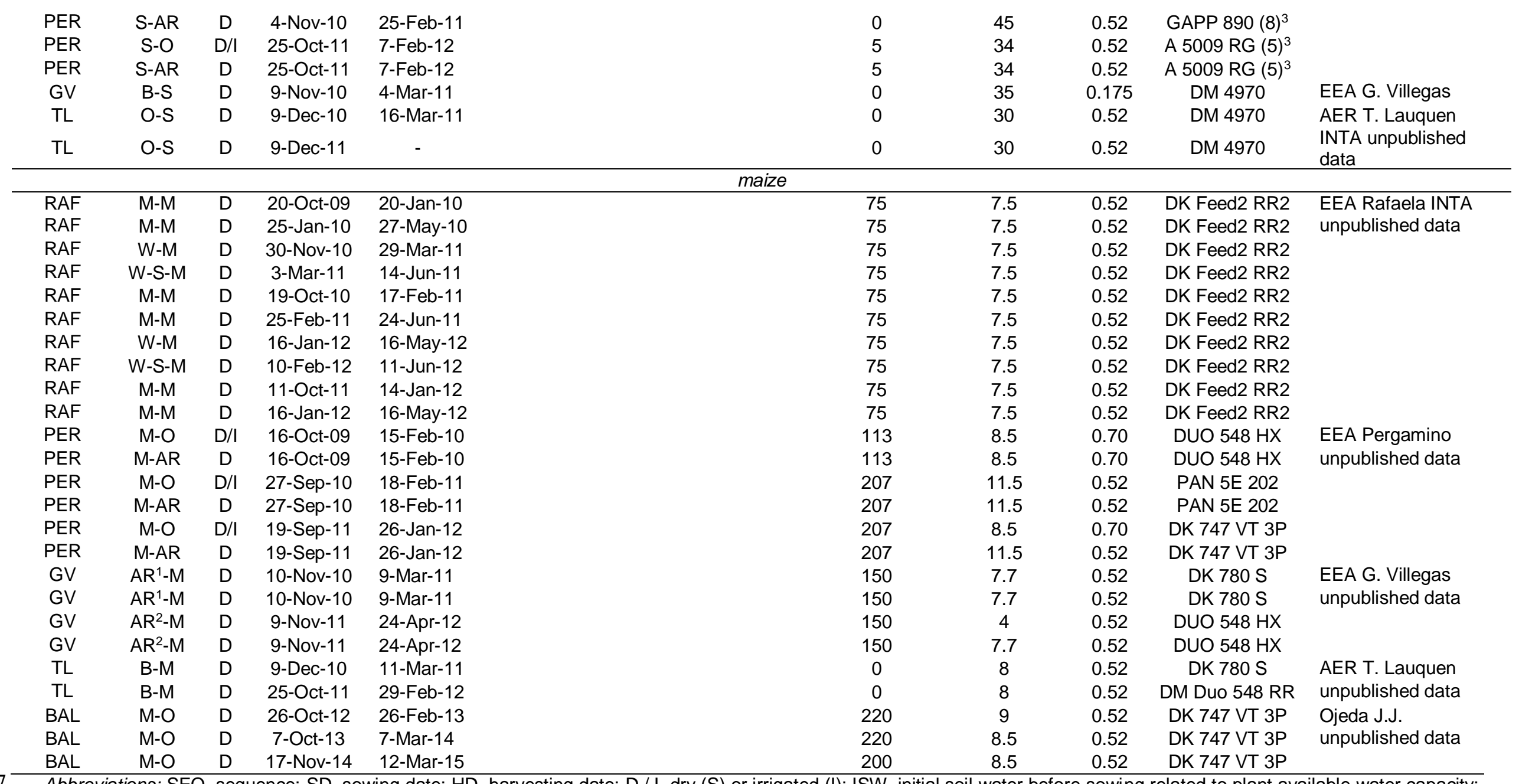

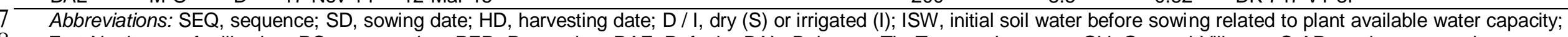
Fert N, nitrogen fertilization; RS, row spacing; PER, Pergamino; RAF, Rafaela; BAL, Balcarce; TL, Trenque Lauquen; GV, General Villegas; S-AR, soybean-annual ryegrass; M-AR, maize-annual ryegrass; AR-M, annual ryegrass-maize; M-O, maize-oats; S-O, soybean-oats; O-S, oats-soybean; W-M, wheat-maize; W-S-M, wheat-soybean-maize; B-

$\mathrm{S}$, barley-soybean; B-M, barley-maize; S-AR, soybean-annual ryegrass; M-M, maize-maize.

${ }_{1}$ Annual ryegrass with several harvests (grazing simulation)

2 Annual ryegrass with only one harvest (silage simulation).

${ }^{3}$ Maturity group. 
14 Table 3. Statistical summary indicating the performance of the Agricultural Production Systems Simulator in predicting the crop DM yield.

\begin{tabular}{|c|c|c|c|c|c|c|c|c|c|c|c|c|c|}
\hline & \multicolumn{6}{|c|}{ Crop } & \multicolumn{6}{|c|}{ Location } & \multirow[b]{2}{*}{ Total } \\
\hline & $\begin{array}{c}\text { annual } \\
\text { ryegrass }\end{array}$ & oats & barley & wheat & soybean & maize & RAF & PER & PERI & GV & TL & $\mathrm{BAL}$ & \\
\hline No. Obs. & 34 & 47 & 5 & 4 & 13 & 24 & 16 & 60 & 26 & 11 & 6 & 8 & 127 \\
\hline Observed mean $\left(\mathrm{Mg} \mathrm{ha}^{-1}\right)$ & 1.4 & 1.5 & 2.7 & 4.8 & 5.9 & 14.9 & 12.6 & 2.8 & 4.2 & 1.9 & 2.4 & 8.7 & 4.6 \\
\hline Modelled mean (Mg ha-1) & 1.2 & 1.2 & 4.4 & 5.9 & 6.5 & 13.7 & 11.0 & 2.7 & 3.9 & 2.5 & 3.6 & 8.9 & 4.4 \\
\hline Observed SD $\left(\mathrm{Mg} \mathrm{ha}^{-1}\right)$ & 0.7 & 0.8 & 1.5 & 1.6 & 2.5 & 6.1 & 6.2 & 3.9 & 5.6 & 1.5 & 1.1 & 9.4 & 5.9 \\
\hline Modelled SD (Mg ha-1) & 0.8 & 0.8 & 1.3 & 2.2 & 3.2 & 6.2 & 4.0 & 4.1 & 6.4 & 1.9 & 1.2 & 10.0 & 5.7 \\
\hline RMSE (Mg ha-1) & 0.7 & 0.6 & 1.7 & 1.6 & 1.4 & 3.4 & 3.3 & 0.9 & 1.7 & 1.1 & 1.5 & 2.0 & 1.7 \\
\hline CCC & 0.46 & 0.77 & 0.90 & 0.79 & 0.90 & 0.86 & 0.84 & 0.98 & 0.96 & 0.84 & 0.53 & 0.98 & 0.96 \\
\hline
\end{tabular}

${ }^{1}$ For this analysis was used the re-parametrized APSIM Weed module by Ojeda et al. (2016).

Abbreviations: No. Obs., Number of observations; SD, standard deviation; RMSE, root mean square error; CCC, concordance correlation coefficient; RAF, Rafaela; PER

Pergamino dryland; PERI, Pergamino irrigated; GV, General Villegas; TL, Trenque Lauquen; BAL, Balcarce. 
19 Table 4. Statistical summary indicating the performance of Agricultural Production

20 Systems Simulator in predicting the dry matter yield of forage crop sequences.

\begin{tabular}{|c|c|c|c|c|c|c|c|c|c|c|}
\hline & RAF & PER & PERI & GV & $\mathrm{TL}$ & BAL & Y1 & Y2 & Y3 & Total \\
\hline No. Obs. & 7 & 11 & 6 & 4 & 3 & 2 & 14 & 13 & 6 & 33 \\
\hline Observed mean $\left(\mathrm{Mg} \mathrm{ha}^{-1}\right)$ & 28.7 & 15.8 & 19.7 & 5.2 & 4.3 & 27.9 & 19.1 & 16.9 & 16.2 & 17.7 \\
\hline Modelled mean (Mg ha-1) & 25.0 & 16.0 & 20.4 & 7.6 & 6.7 & 26.5 & 18.2 & 18.0 & 14.8 & 17.5 \\
\hline Observed SD $\left(\mathrm{Mg} \mathrm{ha}^{-1}\right)$ & 7.6 & 4.3 & 5.4 & 1.3 & 0.4 & 6.3 & 11.4 & 9.1 & 7.4 & 9.7 \\
\hline Modelled SD $\left(\mathrm{Mg} \mathrm{ha}^{-1}\right)$ & 4.9 & 4.9 & 6.9 & 1.5 & 2.1 & 10.2 & 9.3 & 7.8 & 6.5 & 8.1 \\
\hline RMSE (Mg ha-1) & 5.0 & 2.4 & 2.3 & 2.5 & 3.1 & - & 3.4 & 3.2 & 2.7 & 3.2 \\
\hline CCC & 0.83 & 0.86 & 0.93 & 0.86 & - & - & 0.95 & 0.93 & 0.93 & 0.93 \\
\hline
\end{tabular}

21 Abbreviations: No. Obs., Number of observations; SD, standard deviation; RMSE, root mean square error; 22 CCC, concordance correlation coefficient; RAF, Rafaela; PER Pergamino dryland; PERI, Pergamino 23 irrigated; GV, General Villegas; TL, Trenque Lauquen; BAL, Balcarce; Y1, year 1; Y2, year 2; Y3, year 3. 
24 Table 5. Statistical summary indicating the performance of Agricultural Production

25 Systems Simulator in predicting seasonal and annual Water Productivity (WP).

\begin{tabular}{|c|c|c|c|c|c|c|c|c|c|c|}
\hline \multicolumn{11}{|c|}{ Seasonal WP } \\
\hline & RAF & PER & PERI & GV & $\mathrm{TL}$ & BAL & $\mathrm{Y} 1$ & Y2 & Y3 & Total \\
\hline No. Obs. & 16 & 60 & 26 & 11 & 6 & 8 & 51 & 45 & 31 & 127 \\
\hline Observed mean $\left(\mathrm{g} \mathrm{m}^{-2} \mathrm{~mm}^{-1}\right)$ & 4.3 & 3.4 & 3.3 & 2.3 & 1.2 & 3.5 & 3.6 & 3.7 & 2.3 & 3.3 \\
\hline Modelled mean $\left(\mathrm{g} \mathrm{m}^{-2} \mathrm{~mm}^{-1}\right)$ & 3.8 & 2.6 & 2.0 & 3.1 & 1.8 & 3.7 & 2.7 & 3.1 & 2.0 & 2.7 \\
\hline Observed SD ( $\left.\mathrm{g} \mathrm{m}^{-2} \mathrm{~mm}^{-1}\right)$ & 1.5 & 3.1 & 3.8 & 0.8 & 0.4 & 1.5 & 3.1 & 2.9 & 2.5 & 2.9 \\
\hline Modelled SD $\left(\mathrm{g} \mathrm{m}^{-2} \mathrm{~mm}^{-1}\right)$ & 1.0 & 2.0 & 1.8 & 1.6 & 1.1 & 1.8 & 1.8 & 1.8 & 2.0 & 1.9 \\
\hline RMSE $\left(\mathrm{g} \mathrm{m}^{-2} \mathrm{~mm}^{-1}\right)$ & 1.3 & 2.0 & 2.5 & 1.4 & 1.0 & 0.7 & 2.0 & 2.2 & 1.1 & 1.9 \\
\hline $\mathrm{CCC}$ & 0.55 & 0.74 & 0.73 & 0.42 & 0.51 & 0.90 & 0.72 & 0.58 & 0.89 & 0.71 \\
\hline \multicolumn{11}{|c|}{ Annual WP } \\
\hline & RAF & PER & PERI & GV & TL & BAL & Y1 & Y2 & Y3 & Total \\
\hline No. Obs. & 7 & 11 & 6 & 4 & 3 & 2 & 14 & 13 & 6 & 33 \\
\hline Observed mean $\left(\mathrm{g} \mathrm{m}^{-2} \mathrm{~mm}^{-1}\right)$ & 4.1 & 1.8 & 1.9 & 0.8 & 0.7 & 4.3 & 2.3 & 2.4 & 2.0 & 2.3 \\
\hline Modelled mean $\left(\mathrm{g} \mathrm{m}^{-2} \mathrm{~mm}^{-1}\right)$ & 3.6 & 1.8 & 1.8 & 1.2 & 1.1 & 4.0 & 2.1 & 2.5 & 1.7 & 2.2 \\
\hline Observed SD $\left(\mathrm{g} \mathrm{m}^{-2} \mathrm{~mm}^{-1}\right)$ & 0.7 & 0.5 & 0.9 & 0.3 & 0.2 & 0.1 & 1.5 & 1.4 & 1.3 & 1.4 \\
\hline Modelled SD $\left(\mathrm{g} \mathrm{m}^{-2} \mathrm{~mm}^{-1}\right)$ & 0.3 & 0.6 & 1.1 & 0.4 & 0.4 & 0.6 & 1.2 & 1.2 & 1.1 & 1.2 \\
\hline RMSE $\left(\mathrm{g} \mathrm{m}^{-2} \mathrm{~mm}^{-1}\right)$ & 0.7 & 0.2 & 0.4 & 0.4 & 0.5 & - & 0.4 & 0.4 & 0.4 & 0.4 \\
\hline $\mathrm{CCC}$ & 0.62 & 0.96 & 0.93 & 0.91 & - & - & 0.95 & 0.94 & 0.98 & 0.94 \\
\hline
\end{tabular}

26 Abbreviations: No. Obs., Number of observations; SD, standard deviation; RMSE, root mean square error; 27 CCC, concordance correlation coefficient; RAF, Rafaela; PER Pergamino dryland; PERI, Pergamino 28 irrigated; GV, General Villegas; TL, Trenque Lauquen; BAL, Balcarce; Y1, year 1; Y2, year 2; Y3, year 3. 
Table 6. Statistical summary of the linear regression between the observed and modelled Water Productivity (WP) of winter crops (oats, wheat, annual ryegrass and barley) and soybean, and maize $v$. cumulative seasonal annual rainfall plus irrigation and between the observed and modelled Water Productivity (WP) of forage crop sequences $v$. cumulative seasonal annual rainfall plus irrigation.

\begin{tabular}{|c|c|c|}
\hline \multicolumn{3}{|c|}{ Seasonal WP v. cumulative seasonal rainfall + irrigation } \\
\hline & winter crops + soybean & maize \\
\hline No. Obs. & 107 & 20 \\
\hline \multicolumn{3}{|l|}{ Observed data } \\
\hline Adjusted logarithmic regression & $y=385.56 x^{-0.668}$ & $y=10414 x^{-0.916}$ \\
\hline $\mathrm{R}^{2}$ & 0.605 & 0.808 \\
\hline$P$ value & $<0.001$ & $<0.001$ \\
\hline \multicolumn{3}{|l|}{ Modelled data } \\
\hline Adjusted logarithmic regression & $y=151.6 x^{-0.488}$ & $y=3379 x^{-0.754}$ \\
\hline $\mathrm{R}^{2}$ & 0.424 & 0.696 \\
\hline$P$ value & $<0.001$ & $<0.001$ \\
\hline \multicolumn{3}{|c|}{ Annual WP v. cumulative annual rainfall + irrigation } \\
\hline & \multicolumn{2}{|c|}{ forage crop sequences } \\
\hline No. Obs. & \multicolumn{2}{|c|}{$26^{1}$} \\
\hline \multicolumn{3}{|l|}{ Observed data } \\
\hline Adjusted logarithmic regression & \multicolumn{2}{|c|}{$y=8.65 e^{-0.002 x}$} \\
\hline $\mathrm{R}^{2}$ & \multicolumn{2}{|c|}{0.448} \\
\hline$P$ value & \multicolumn{2}{|c|}{$<0.001$} \\
\hline \multicolumn{3}{|l|}{ Modelled data } \\
\hline Adjusted logarithmic regression & \multicolumn{2}{|c|}{$y=9.12 e^{-0.002 x}$} \\
\hline $\mathrm{R}^{2}$ & \multicolumn{2}{|c|}{0.531} \\
\hline$P$ value & \multicolumn{2}{|c|}{$<0.001$} \\
\hline
\end{tabular}




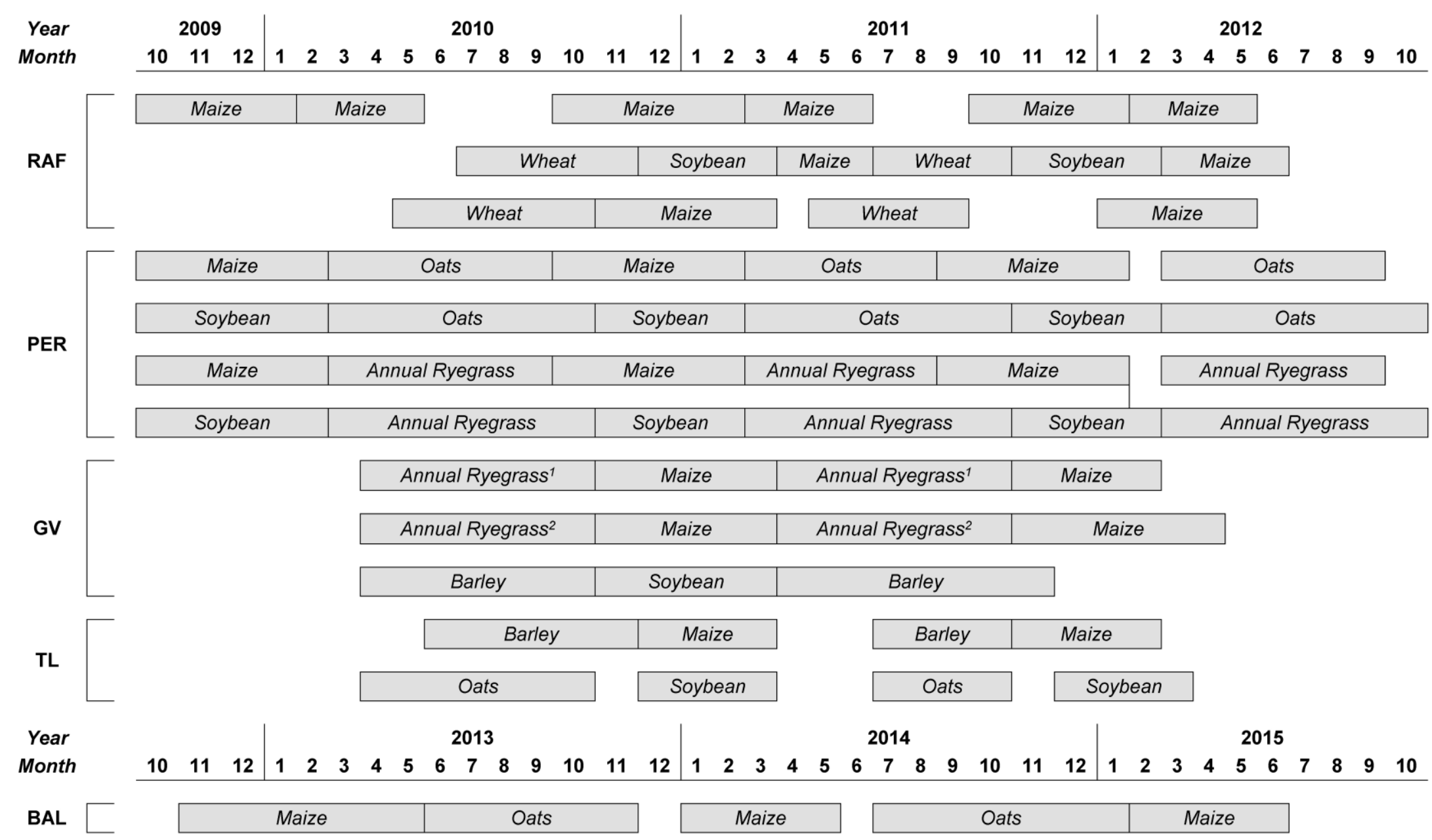

Figure 1. Schematic representation of forage crop sequences growing in Rafaela (RAF), Pergamino (PER), General Villegas (GV), Trenque Lauquen (TL) and Balcarce from 2009 to 2015. Superscript 1 and 2 indicates annual ryegrass with successive harvests and with only one harvest, respectively. 

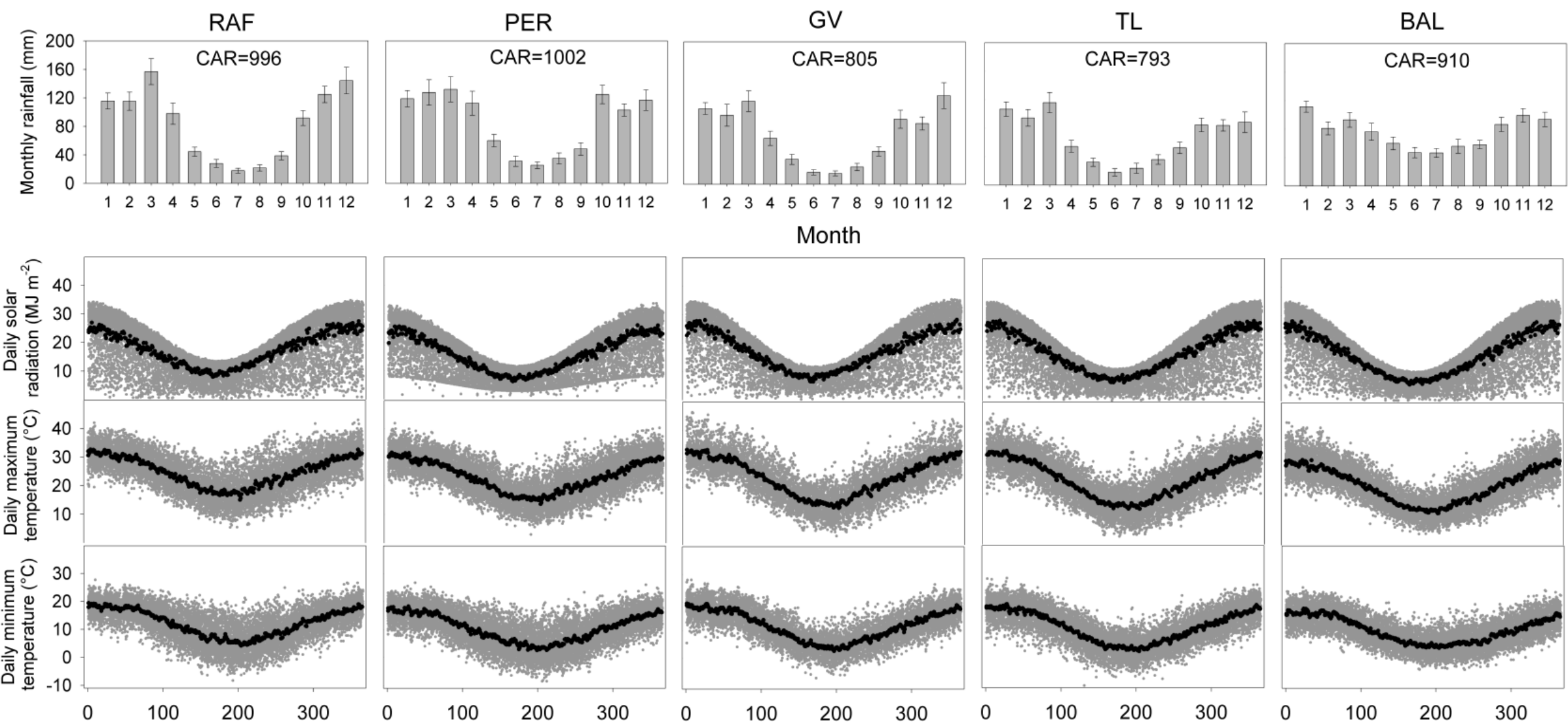

Month
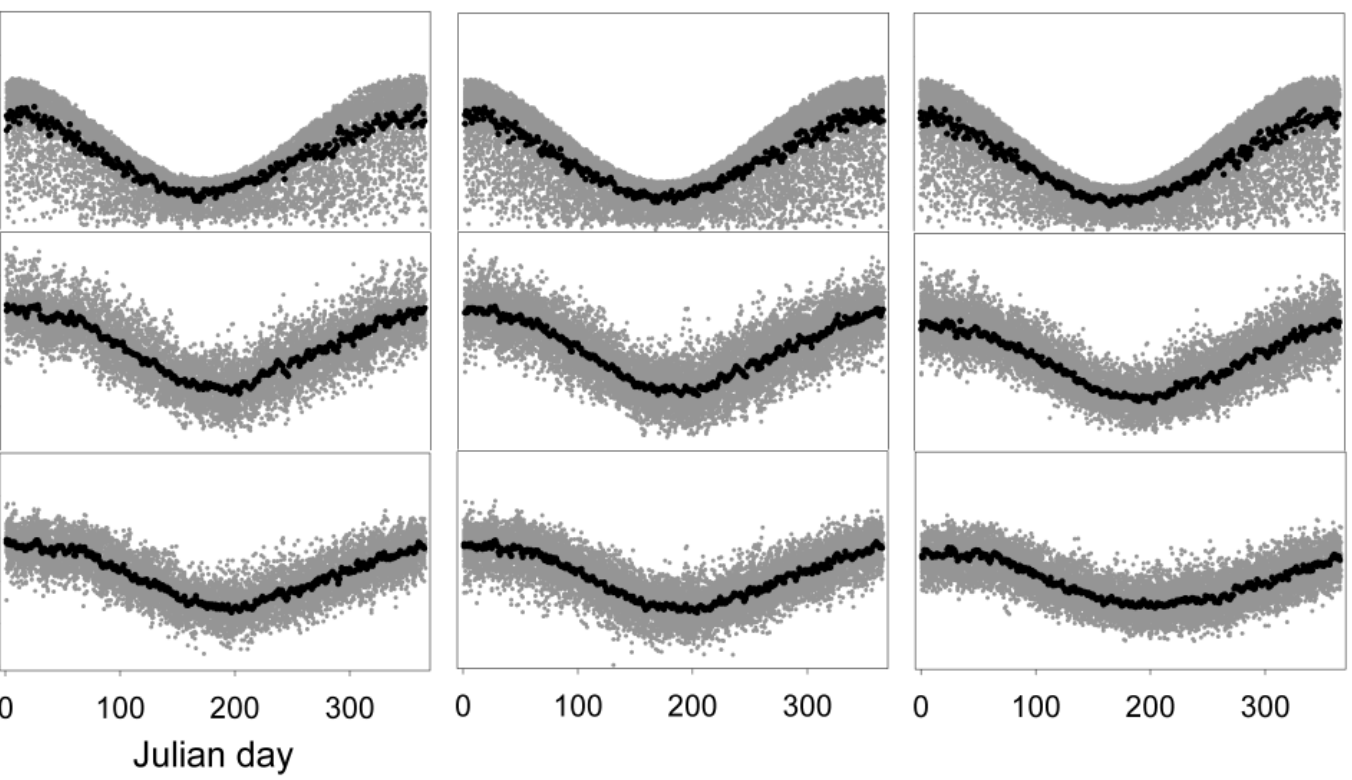

Figure 2. Historical climate data in Rafaela (RAF), Pergamino (PER), General Villegas (GV), Trenque Lauquen (TL) and Balcarce (BAL) from 1983 to 2013. Black points indicate long-term averages. Numbers for the $x$-axis in panels a, b, c, $d$ and e indicates the month of the year from January (1) to December (12) and error bars are the standard error for the period. Grey points are individual daily values during the 30 -year period from 1January (Julian day 1) to 31-December (Julian day 365). Cumulative annual rainfall (CAR). 


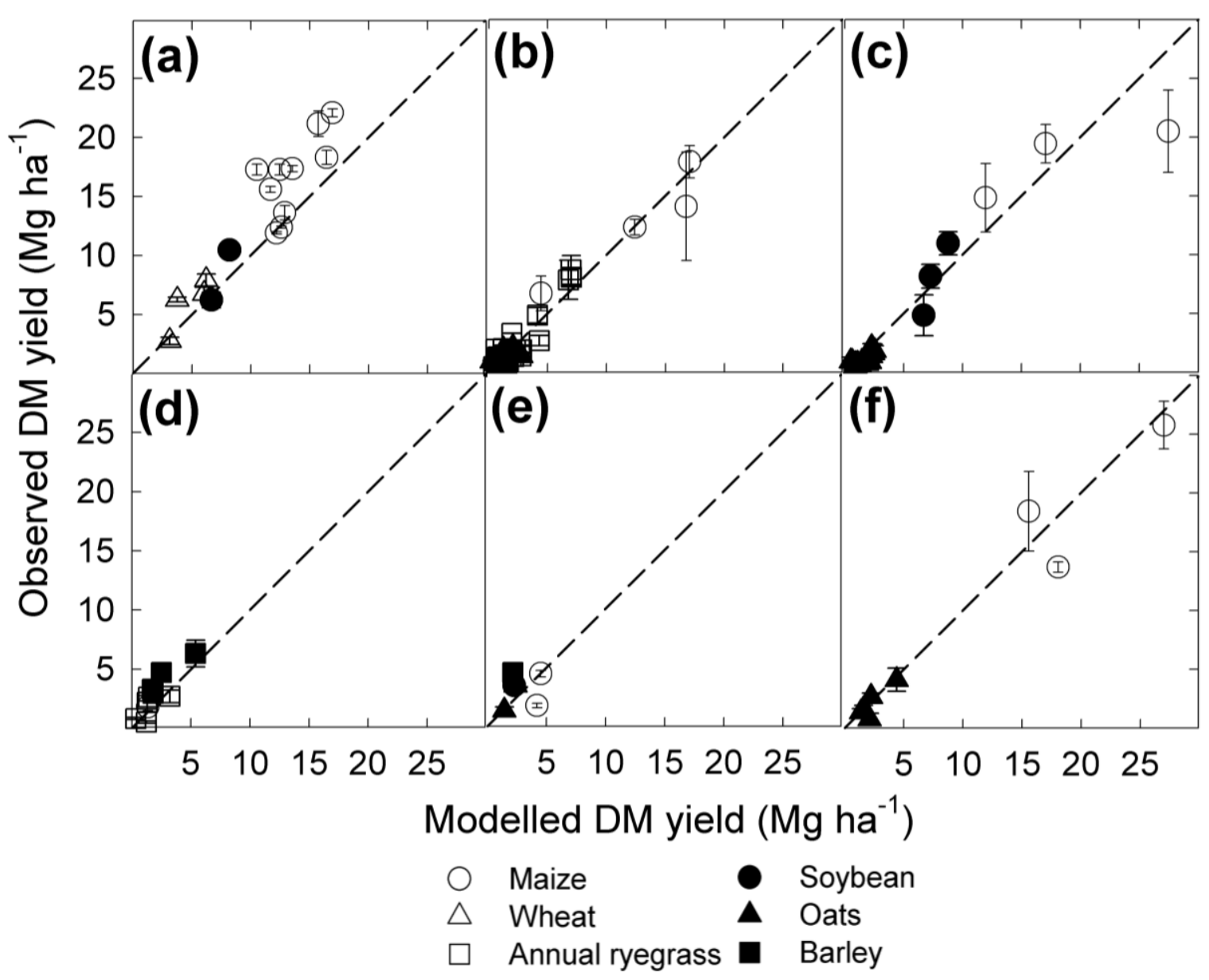

Figure 3. Observed v. modelled crop dry matter (DM) yield in (a) Rafaela, (b) Pergamino dryland, (c) Pergamino irrigated, (d) General Villegas, (e) Trenque Lauquen and (f) Balcarce. The diagonal line represents the line $1: 1$, i.e. $y=x$. The vertical bars indicate the standard deviation of the mean. 


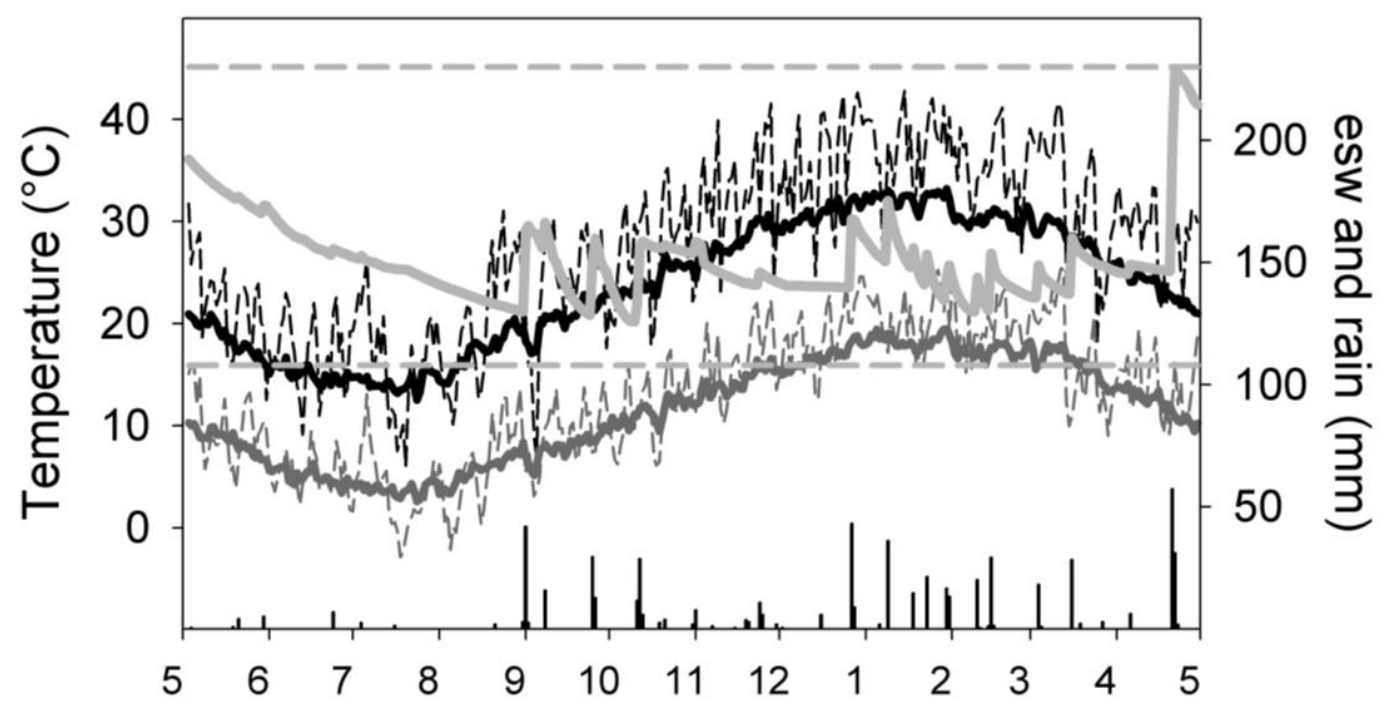

Figure 4. Daily maximum (dotted black line) and minimum air temperature (dotted dark grey line), modelled extractable soil water (esw, solid grey line) and rain (black bars) from May2010 to May-2011 in General Villegas. Numbers for the x-axis indicates the month of the year from January (1) to December (12). Solid black and dark grey lines represent the historical daily maximum and minimum air temperature, respectively. Dotted grey lines represent the lower and upper drainage limits for the Typic Hapludoll soil at this location. 


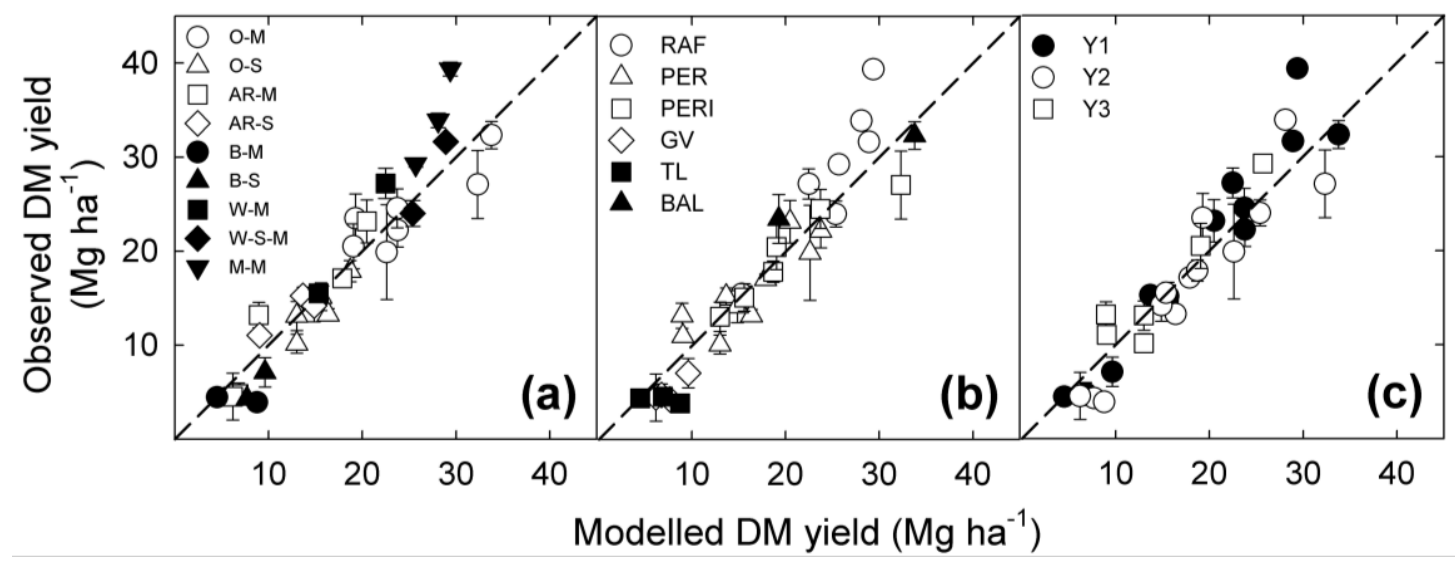

Figure 5. Observed $v$. modelled forage crop sequences dry matter (DM) yield by (a) sequence type, (b) location and (c) year. The diagonal line represents the adjusted line 1:1, i.e. $y=x$. The vertical bars indicate the standard deviation of the mean. O-M, oats-maize; O-S, oats-soybean; AR-M, annual ryegrass-maize; AR-S, annual ryegrass-soybean; B-M, barley-maize; B-S, barleysoybean; W-M, wheat-maize; W-S-M, wheat-soybean-maize; M-M, maize-maize; RAF, Rafaela; PER, Pergamino dryland; PERI, Pergamino irrigated; GV, General Villegas; TL, Trenque Lauquen; BAL, Balcarce; Y1, year 1; Y2, year 2 and $Y 3$, year 3. 

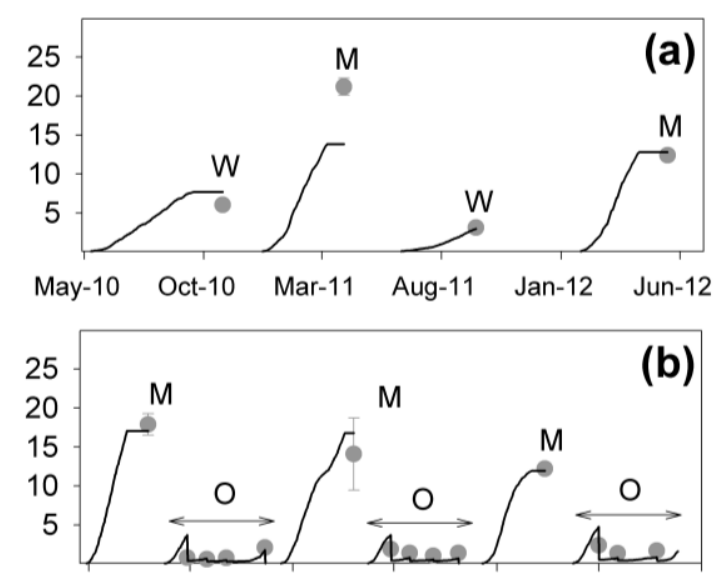

Nov-09 May-10 Nov-10 May-11 Nov-11 May-12 Nov-12

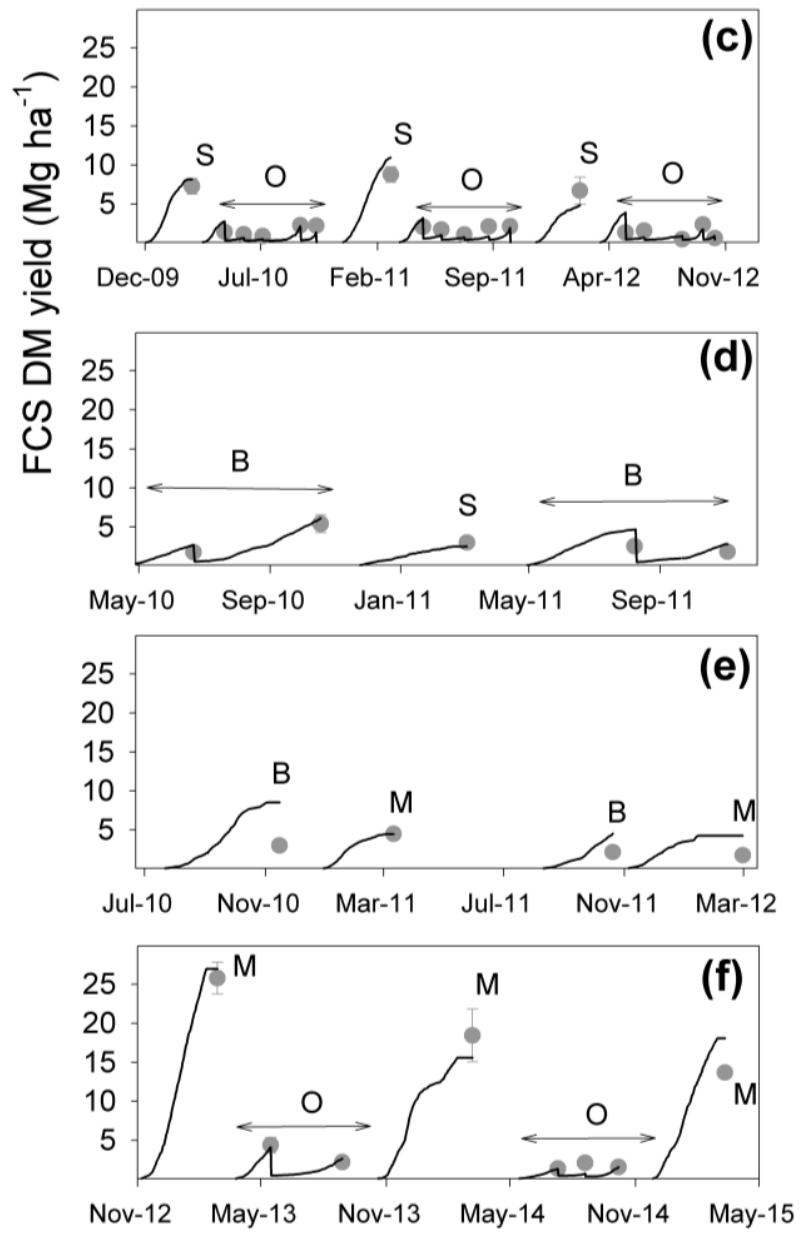

Figure 6. Modelled (solid black line) and observed (grey points) dry matter (DM) yield for selected forage crop sequences (FCS): (a) wheat-maize in Rafaela, (b) maize-oats in Pergamino dryland, (c) soybean-oats in Pergamino irrigated (d) barley-soybean in General Villegas, (e) barley-maize in Trenque Lauquen and (f) maize-oats in Balcarce. Capped vertical bars represent the range in observed values where such data were available. W, wheat; M, maize; O, oats; B, barley. 


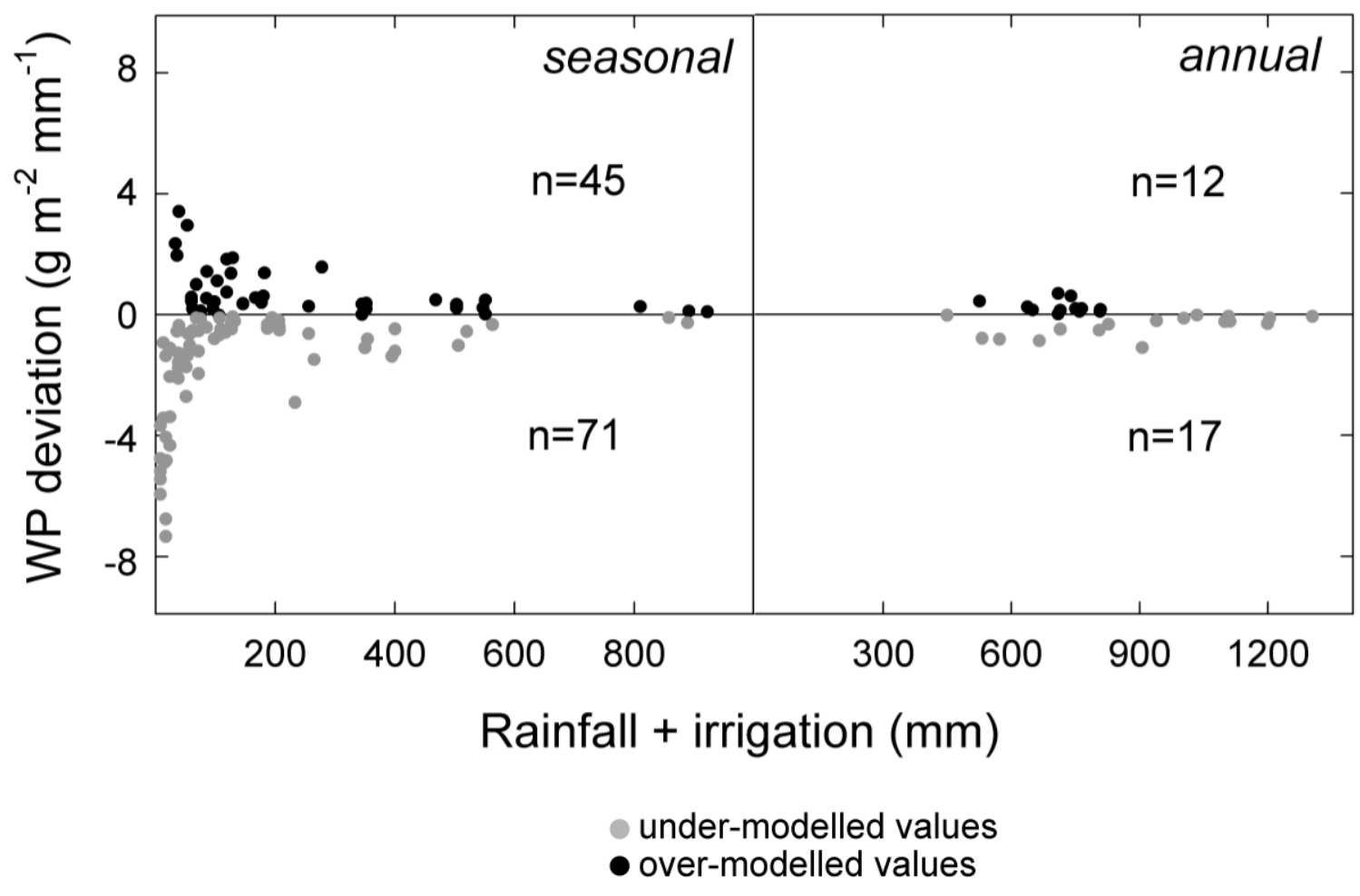

Figure 7. Water productivity (WP) deviation values from the observed values $v$. rainfall + irrigation on a seasonal- and annual-base during 7 years (2009-2015) for different forage crop sequences growing in the Argentinian Pampas. 

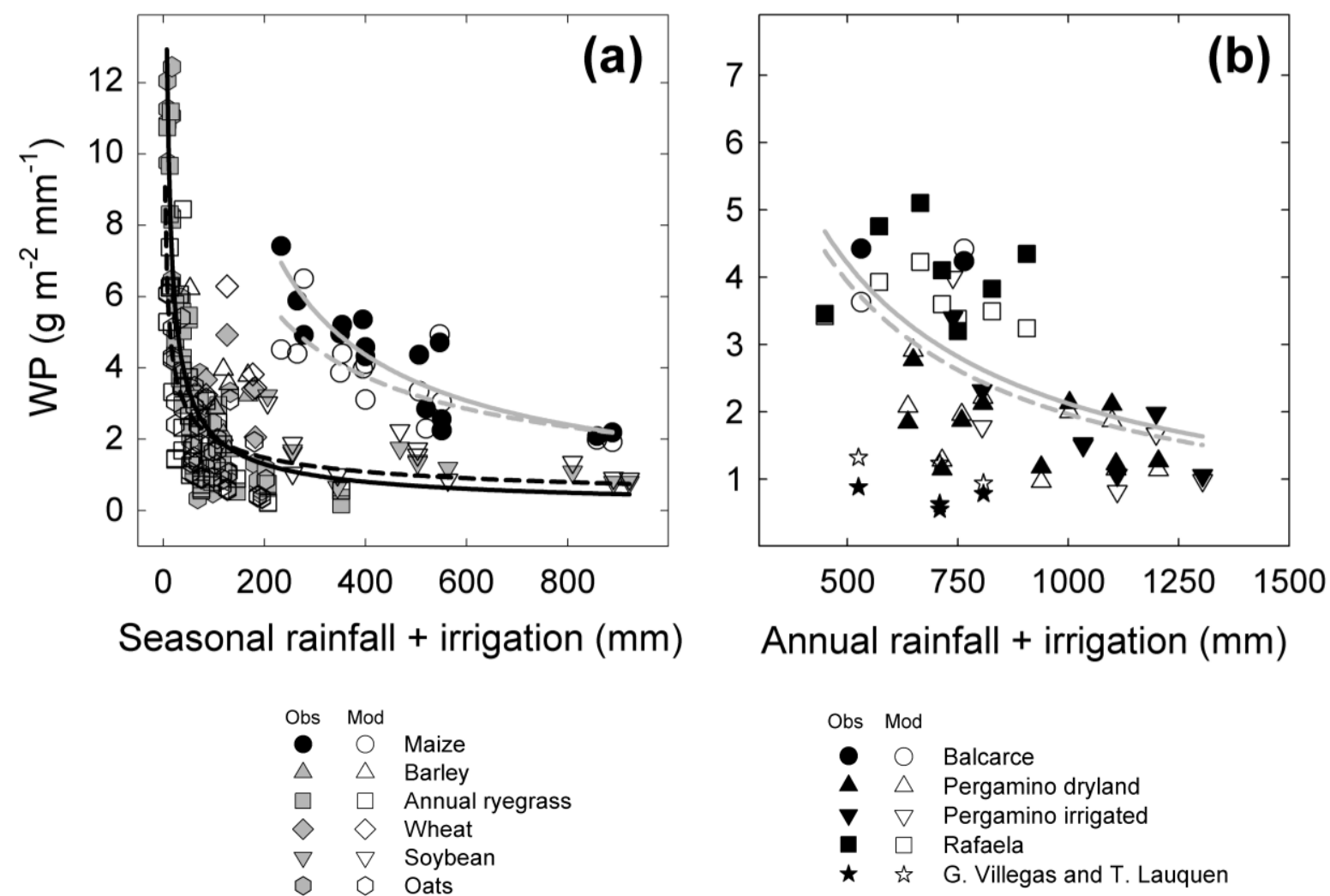

Figure 8. Observed (closed symbols) and modelled (open symbols) Water Productivity (WP) v. rainfall + irrigation on a (a) seasonal- and (b) annual-base. Solid and dotted lines represent the regression lines for observed and modelled data, respectively. The regression line shown in panel b was calculated excluding data from General Villegas and Trenque Lauquen. The regression equations are shown in the Table 6. 